\title{
Tectonics
}

\author{
RESEARCH ARTICLE \\ 10.1029/2020TC006404 \\ Key Points: \\ - Previously unknown faults that \\ belong to the North Anatolian Fault \\ system have been discovered in \\ Lake Iznik through geophysical \\ surveys (from multibeam \\ bathymetry and high-frequency \\ seismic reflection data) \\ - Assessment of the recent activity \\ of the Iznik Fault, based on \\ multiproxy analysis of sediment \\ cores from each side of the fault \\ - Evidence for the timing of the last \\ rupture corresponding to the \\ 1065 CE historical earthquake, \\ which had significantly impacted \\ the city of Iznik
}

Supporting Information:

- Supporting Information S1

Correspondence to:

R. Gastineau,

renaldo.gastineau@univ-grenoblealpes.fr

Citation:

Gastineau, R., de Sigoyer, J.,

Sabatier, P., Fabbri, S. C., Anselmetti, F. S., Develle, A. L., et al. (2021). Active subaquatic fault segments in Lake Iznik along the middle strand of the North Anatolian Fault, NW Turkey. Tectonics, 40, e2020TC006404. https://doi.org/ 10.1029/2020TC006404

Received 30 JUN 2020 Accepted 3 NOV 2020

Accepted article online 9 DEC 2020

Author Contributions:

Conceptualization: J. de Sigoyer

Data curation: F. Niessen, A. C.

Gebhardt

Formal analysis: R. Gastineau, P.

Sabatier

Investigation: F. S. Anselmetti

Methodology: R. Gastineau, S. C.

Fabbri, A. L. Develle, M. Şahin, S.

Gündüz

Writing - original draft: R. Gastineau Writing - review \& editing: $\mathrm{R}$.

Gastineau, J. de Sigoyer, P. Sabatier, S. C. Fabbri, F. S. Anselmetti, A. L. Develle, M. Şahin, S. Gündüz, F. Niessen, A. C. Gebhardt

(C)2020. American Geophysical Union. All Rights Reserved.

\section{Active Subaquatic Fault Segments in Lake Iznik Along the Middle Strand of the North Anatolian Fault, NW Turkey}

\author{
R. Gastineau ${ }^{1,2}$ (D) J. de Sigoyer ${ }^{1}$, P. Sabatier ${ }^{2}$, S. C. Fabbri ${ }^{3}$ (D) F. S. Anselmetti ${ }^{3}$, A. L. Develle ${ }^{2}$, \\ M. Şahin ${ }^{4}$, S. Gündüz ${ }^{4}$ (D), F. Niessen ${ }^{5}$, and A. C. Gebhardt ${ }^{5}$ iD \\ ${ }^{1}$ University Grenoble Alpes, University Savoie Mont Blanc, CNRS, IRD, IFSTTAR, Grenoble, France, ${ }^{2}$ EDYTEM, \\ Université Savoie Mont-Blanc, Université Grenoble Alpes, CNRS, Le Bourget-du-Lac, France, ${ }^{3}$ Institute of Geological \\ Sciences and Oeschger Centre for Climate Change Research, University of Bern, Bern, Switzerland, ${ }^{4}$ Fen-Edebiyat \\ Fakültesi, Arkeoloji Bölümü, Görükle, Bursa Uludağ Üniversitesi, Bursa, Turkey, ${ }^{5}$ Alfred Wegener Institute (AWI) \\ Helmholtz Centre for Polar and Marine Research, Bremerhaven, Germany
}

\begin{abstract}
The seismic activity of the middle strand of the North Anatolian Fault (MNAF), Northwestern Turkey, is debated because of its quiescence during the instrumental period, in contrast to a significant historical activity documented by several chronicles over the last two millennia. Here, we focus on Lake Iznik, bordered by the MNAF, to get a new insight into its long-term seismicity and its tectonic setting. The study of lacustrine sediment cores reveals 14 earthquake-induced turbidites since their ages correspond to seismic events during the past two millennia. Bathymetry and high-resolution seismic reflection data allow to describe two hitherto unknown subaquatic active fault structures (the South Boyalica and Iznik faults) that belong to the MNAF system. Sediment cores sampled on both sides of the Iznik Fault document an event deposit and a sedimentary unit vertically offset of $\sim 40 \mathrm{~cm}$ interpreted as the last rupture during the $1065 \mathrm{CE}$ destructive earthquake. Older events are supposed on this fault more than thousand years ago. Further studies will help to estimate the horizontal co-seismic offset of this oblique-slip fault and the calendar of older ruptures. The current seismic gap of thousand years on this segment greatly increases the seismic hazard in this region and must be considered in the seismic risk assessment of the NAF system.
\end{abstract}

Plain Language Summary During large earthquakes, sediments are generally transported from lake slopes to the lake basin. The resulting event deposits can provide information on the recurrence of past regional earthquakes, which is crucial for seismic hazard assessment. In this study, we discovered two underwater fault structures in Lake Iznik, using geophysical methods. Studying the sedimentation on both sides of the southernmost fault, we observed an increased sedimentation rate on the hanging wall of the fault immediately after an event deposit, dated to $1077 \pm 77$ cal. CE. We interpreted these indicators as resulting from a co-seismic displacement along the fault plane, linked to the $1065 \mathrm{CE}$ historical earthquake, which had significantly impacted the city of Iznik. We also show that most of the other event deposits in the sediment cores are confidently associated to 14 historical earthquakes since 2,000 years.

\section{Introduction}

Earthquakes are the costliest and deadliest natural events in Turkey with about 100,000 deaths in the last century (Öcal, 2019). Despite their lower frequency compared to other events such as floods, the impact of earthquakes cannot be ignored in this densely populated part of the world. The seismic hazard in the northwestern part of Turkey is mainly linked to the North Anatolian Fault (NAF), a 1,500 km long right-lateral strike-slip fault, which accommodates the westward migration of the Anatolian microplate, away from the Eurasian/Arabian collision (Reilinger et al., 2006).

In its western termination, the NAF zone displays a complex organization as it is divided into three branches (Figure 1). Its northern strand (NNAF) continues south of Istanbul through the Marmara Sea (e.g., Armijo et al., 2005). Its middle strand (MNAF) borders the south of two successive basins, known as the Geyve-Pamukova Basin and the Iznik Basin, which hosts Lake Iznik and continues through the Gemlik Bay to the southern shore of the Marmara Sea (Figure 1). Its southern strand (SNAF) is less pronounced in the landscape and extends across the Bursa Province (Figure 1). With a relative horizontal motion 


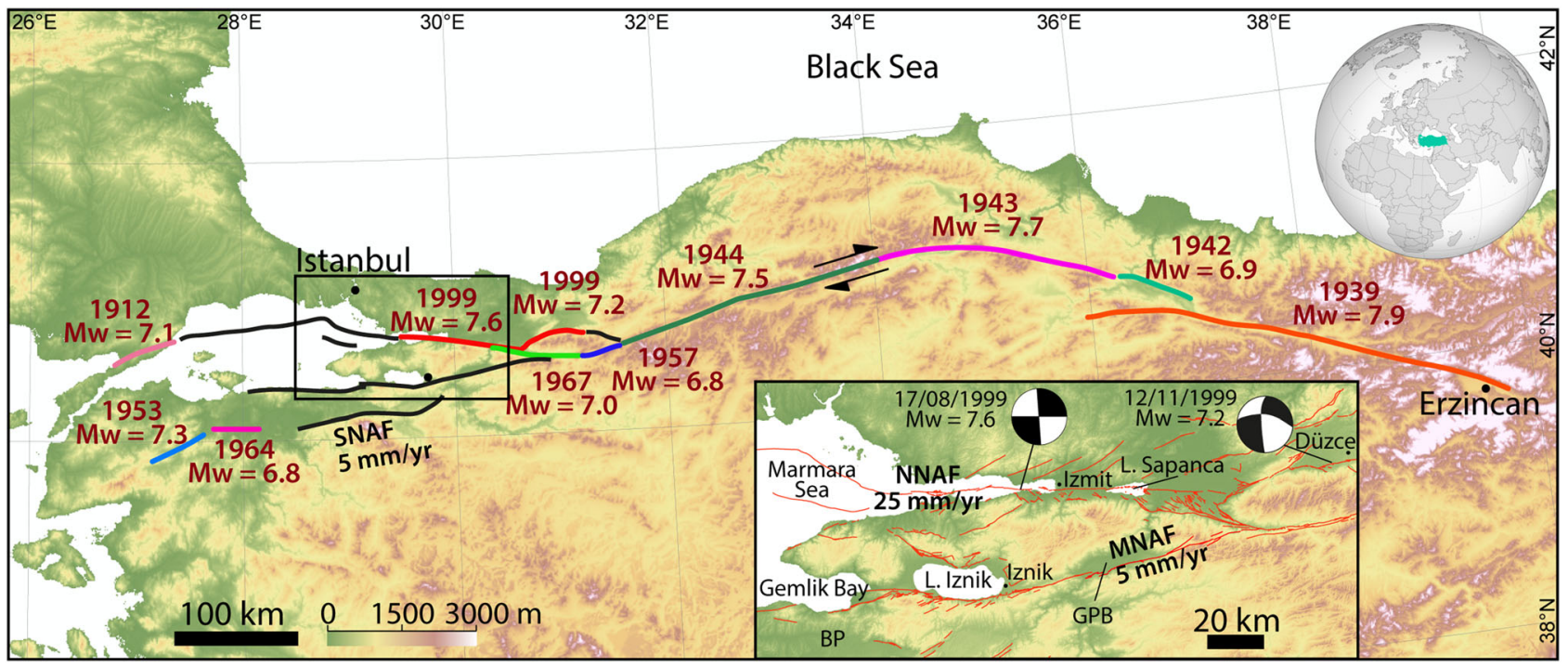

Figure 1. Shuttle Radar Topography Mission (SRTM-1 arc-second resolution; https://earthexplorer.usgs.gov/) digital elevation model (DEM) with the different fault strands that ruptured during the major earthquakes of the twentieth century (respective age, location, and moment magnitudes indicated from USGS earthquake catalog; https://earthquake.usgs.gov/earthquakes/search/ and Stein et al., 1997). The seismic gaps at the western termination of the NAF are shown as black lines. Inset is a zoom of the studied part with the different strands of the NAF. GPB refers to the Geyve-Pamukova Basin and BP to the Bursa Province. Focal mechanism solutions are retrieved from Tibi et al. (2001). Active faults are shown in red (Benjelloun, 2017; Emre et al., 2018).

estimated around $5 \mathrm{~mm} / \mathrm{yr}$ by GPS (Ergintav et al., 2014), both MNAF and SNAF show a deformation rate fivefold smaller than the NNAF ( $25 \mathrm{~mm} / \mathrm{yr}$ ) (Reilinger et al., 2006). This is also reflected by the recent seismicity of the NAF: From 1939 to 1999, a sequence of great earthquakes (moment magnitude Mw > 6.8) shifted westward from Erzincan to Düzce and Izmit (Figure 1; Stein et al., 1997). The last major earthquake on the NNAF occurred in 1999 along the Izmit-Sapanca rupture and was a $7.6 \mathrm{Mw}$ event. A ground-motion study revealed that this fault segment broke with a supershear velocity during the earthquake (Bouchon, 2002). This destructive event caused extensive liquefaction-induced ground deformation on the shores of Lake Sapanca triggering the submergence of a hotel (Cetin et al., 2002). The succession of the earthquakes on the NNAF is explained by the cumulative Coulomb stress along the fault (Stein et al., 1997). According to this concept and several studies with complementary methods, a seismic gap is inferred on the NNAF segment in the Marmara Sea, which was seismically inactive since the eighteenth century (Hubert-Ferrari et al., 2000). This future rupture may lead to a Mw $>7$ earthquake and strike Istanbul (e.g., Armijo et al., 2005; Bulut et al., 2019; Lange et al., 2019; Parsons, 2000). However, these different models only encompass the recent seismicity (since $1700 \mathrm{CE}$ ) on the NNAF branch but do not take into account either the MNAF or the SNAF. While the NNAF produced several major earthquakes since that time (Ambraseys, 2002), the SNAF produced a 7.3 Mw earthquake in 1953 and a 6.9 Mw earthquake in 1964 (Ambraseys, 2002). However, no major earthquake ruptured on the MNAF for several centuries, and a very low seismicity has been recorded during the instrumental period. The last big earthquake on the MNAF may have occurred between the fourteenth and eighteenth centuries CE (Ambraseys, 2002). This long quiescence strongly contrasts with a significant historical tectonic activity on the MNAF. Several chronicles and archeological studies report the partial destruction of the city of Iznik (previously called Nicaea) and surrounding areas following 15 major earthquakes within the last 2,000 years with unknown rupture segments (Ambraseys, 2002; Ambraseys \& Finkel, 1991; Ambraseys \& Jackson, 2000; Benjelloun et al., 2020). The quiescence of the MNAF in recent times may hide a longer seismic recurrence, which possibly is just as hazardous as the NNAF (according to their span of quiescence), but has been underestimated by the models. This study aims to specify the earthquake catalogue in the Iznik area to determine the seismic cycle of the MNAF and to provide new data for the tectonic setting of this fault strand. This study is the first to use the sedimentary record of the Lake Iznik to document past earthquakes along the MNAF. It complements previous studies done close to 
different fault segments of the NNAF in different sub-basins of the Marmara Sea through sediment analysis (e.g., Çağatay et al., 2012; Drab et al., 2012; Eriş et al., 2012; McHugh et al., 2006). It will bring new paleoseismic information in this region.

Lake sediments are continuous archives used to reconstruct past earthquake history (Avşar et al., 2015; Beck, 2009; Moernaut et al., 2017; Monecke et al., 2004; Rapuc et al., 2018; Strasser et al., 2006, 2013; Van Daele et al., 2015; Wilhelm et al., 2016). Compared to historical and terrestrial archives, lake sediments provide a complementary and more continuous paleoseismic record (e.g., Strasser et al., 2013; Wilhelm et al., 2016). Combining on-fault studies such as trenching with studies investigating earthquake-induced turbidites in lakes not only provides direct evidence for fault displacement in the case of surface ruptures (e.g., Beck et al., 2015) but also allows to document seismic events off-fault without surface ruptures (Brocard et al., 2016). We propose here to investigate Lake Iznik using a combined geophysical and sedimentological approach to provide new insights into the seismicity of the Iznik region over the past millennia. These methods have been already used on submarine ocean-floor faults such as in the Marmara Sea or in the Lesser Antilles (e.g., Armijo et al., 2005; Beck et al., 2012; McHugh et al., 2014).

\section{Context}

\subsection{Geological Settings and Previous Studies on the MNAF}

The NAF originated some 11-13 Ma ago within a wider pre-existing shear zone, which became progressively narrower through time (Şengör et al., 2014). While most of NAF segments are known to have a right-lateral kinematics, several segments show oblique (transtensional) kinematics with local deformation partitioning between right-lateral strike-slip and extensional regimes (Doğan et al., 2015; Kurt et al., 2013; Figure 2). The origin of the Iznik Basin is still under debate: it has been interpreted as a superimposed basin evolved due to the intersection of the younger NAF and the Thrace Eskişehir Fault (Öztürk et al., 2009; Yaltırak, 2002) or as a more complex transtensional basin due to MNAF activity (Doğan et al., 2015). The geological inheritance is reflected by the relatively high lithological heterogeneity and tectonic complexity within the watershed (Figure 2a). The Gürle Fault (a segment of the MNAF) has a normal component (Doğan et al., 2015), which explains the current location of the deepest depocentre of Lake Iznik ( $75 \mathrm{~m}$ depth b.1.l.; Figure 2a). This normal component is also expressed by the $100 \mathrm{~m}$ high triangular facets on Lake Iznik's southern shore (Figure 2b). Fault partitioning thus certainly exists; whereas the onshore Gürle Fault accommodates most of the normal component, another fault segment should somewhere accommodate the dextral component (Figure 2b).

At least 15 earthquakes were documented in historic chronicles in Iznik during the last two millennia (Ambraseys, 2002; Ambraseys \& Finkel, 1991; Ambraseys \& Jackson, 2000; Benjelloun et al., 2020). According to these archives, the epicenter of some of them is located on the MNAF (29-32; 121; 368 and 1,065; the 1419 CE earthquake was also recorded on the SNAF so the epicenter location is still under debate). More than 20 trenches carried out on different segments of the MNAF confirmed its activity (e.g., Barka, 1993; Doğan, 2010; Honkura \& Işikara, 1991; Özalp et al., 2013; Uçarkuş, 2002; see Figure 2a for their locations). One to three ruptures were identifying on them but very few of them gave reliable ages. It is therefore difficult to conclude on the precise rupture ages on the different segments of the MNAF, and on their earthquake recurrence rate. The city of Iznik hosts many archeological remains affected by past earthquakes, such as the recently discovered submerged basilica in Lake Iznik (Şahin, 2014; Şahin \& Fairchild, 2018). Through a systematic survey of Earthquake Archeological Effects (EAE) on Iznik's buildings, Benjelloun et al. (2020) showed that three damage episodes are recorded: between the sixth and late eighth centuries CE, between the ninth and late eleventh centuries CE and after the late fourteenth century $\mathrm{CE}$. The second episode is clearly related to an earthquake in $1065 \mathrm{CE}$ that was well described in many local chronicles and caused several damages in Iznik, whereas the two other episodes could be explained by different earthquake scenarios.

\subsection{Lake Catchment}

Lake Iznik (83.5 m a.s.1, $\left.40^{\circ} 26^{\prime} \mathrm{N}, 2^{\circ} 32^{\prime} \mathrm{E}\right)$, formerly known as Lake Askania, is located southeast of the Marmara Region (Bursa Province), east of the Gemlik Bay (Figure 1). It is the fifth largest lake of Turkey, and the largest of the Marmara Region with a N-S and E-W extent of 12 and $32 \mathrm{~km}$, respectively (Figure 2a). The lake has a catchment area of $\sim 1,257 \mathrm{~km}^{2}$ and a surface area of $313 \mathrm{~km}^{2}$. The watershed 


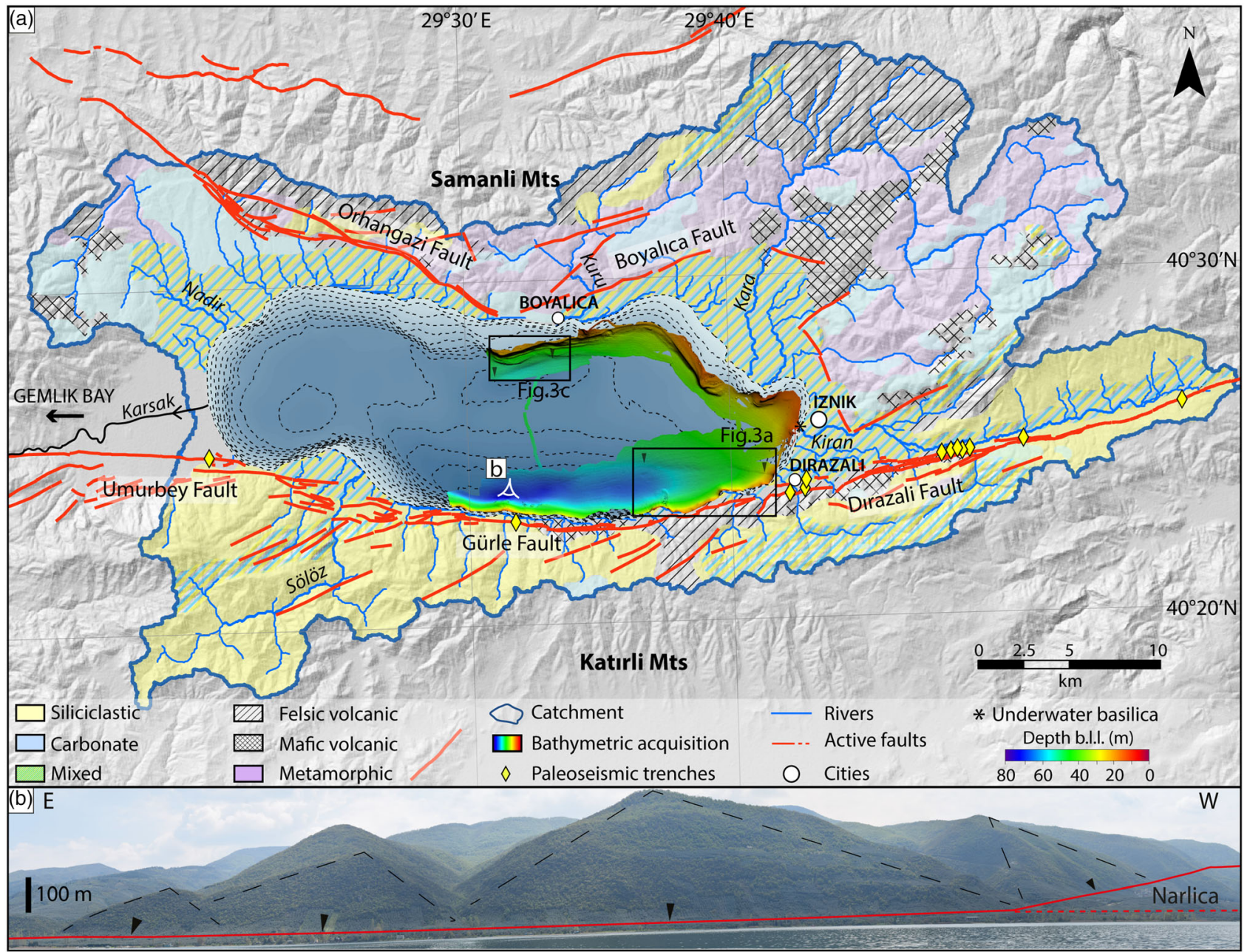

Figure 2. (a) Lithological map of the watershed of Lake Iznik (modified from Viehberg et al., 2012) and limits of its catchment (dark blue line). The hillshade relief is generated from the SRTM DEM (1 arc-second resolution). The main rivers are drawn in blue. The MNAF and other active faults are represented in red (Benjelloun et al., 2017; Doğan et al., 2015; Emre et al., 2018; Ozturk et al., 2009). The bathymetric contour lines in the lake represent $5 \mathrm{~m}$ intervals (DSI), superimposed by the hillshaded bathymetry acquired in this study ( $2 \mathrm{~m}$ grid), with a sun illumination angle/elevation of $20^{\circ} \mathrm{N} / 45^{\circ}$, respectively. A vertical exaggeration of 15 was applied. The color scale represents the depth below lake level (b.1.1.), based on a long-term reference lake level of $83.5 \mathrm{~m}$ above sea level. The black arrows show the visible extremities of the two newly discovered faults. The black rectangles indicate the location of Figure 3. (b) Photography of the southern shore of the lake taken from the lake and facing southward, showing triangular facets (black dashed lines) along the Gürle Fault (black arrows). These patterns highlight the significant normal tectonic component in this area.

shows a heterogeneous geology, with a northern part relatively rich in volcanic, metamorphic rocks and carbonates, while the southern part is mostly composed of siliciclastic sediments with only sporadic carbonate and volcanic sections. Iznik has been an important city throughout history. Different archeological excavations in the area suggest that the first farming activities began 6,000-5,400 BCE (Roodenberg, 2013). Since the first humans settled in the watershed, the land has been cultivated: cereals, olives, and walnuts were among the most important crops in the Iznik area (Miebach et al., 2016). The lake is peanut-shaped with a non-regular shoreline (Figure 2a). A rough bathymetry of the lake, assembled by the General Directorate of Turkish Hydraulic Works (DSI), shows that the lake comprises three sub-basins, reflecting its tectonic complexity (Figure 2a). One isolated sub-basin is located in the western part of the lake, whereas two sub-basins form the central and eastern parts, with one in the North and the deepest one in the South separated by a E-W elongated ridge (Figure 2a). The main inflows are the Sölöz, Nadir, Kuru, Kara, and Kiran rivers (Figure 2a). The only outlet of the lake is the Karsak River, which discharges the waters westward to the Marmara Sea through the Gemlik Bay. The Iznik Basin is bordered by two mountain ranges: The Samanli Mountains (max. elevation 1,227 $\mathrm{m}$ a.s.l.) to the north, and the Katırli Mountains to the south (1,275 m a.s.l.) (Figure 2a). Previous studies of Lake Iznik's 
sediments have provided an up to $36 \mathrm{kyr}$ long paleoclimatic archive (Miebach et al., 2016; Roeser et al., 2012; Ülgen et al., 2012; Viehberg et al., 2012). In these past studies of Lake Iznik's sedimentary archives, no event deposits (except tephra layers) were identified in the sedimentary sequence.

\section{Methodology}

\subsection{Bathymetry}

The bathymetric survey was completed in April 2019 using a fishing boat with a Kongsberg EM2040 multibeam echosounder (Kongsberg Maritime, Horten, Norway, provided by University of Bern) in a single-head configuration ( $1^{\circ}$ by $1^{\circ}$ beam width, $300 \mathrm{kHz}$ standard operating frequency; 400 depth detections per ping). The angular coverage was $148^{\circ}$ maximum, with a coverage of up to $\sim 3$ times water depth on a flat bottom. The transducers and auxiliary sensors Kongsberg Seatex MRU5 + motion sensor (Kongsberg Seatex, Trondheim, Norway), a Trimble SPS361 heading sensor (Trimble Navigation Limited, Sunnyvale, CA, USA), a Leica GX1230 GNSS receiver (Leica Geosystems, Heerbrugg, Switzerland) using the TUSAGA Aktif GEO real-time positioning service (national active fixed GNSS, Turkey; typical position accuracy 2 to $3 \mathrm{~cm}$ ) and a Valeport MiniSVS sound velocity sensor (Valeport Limited, Totnes, UK) were used. The transducers, motion sensor and mini sound velocity sensor were incorporated in a rigid mounting attached to the bow of the ship. The ship speed ranged from $7-9 \mathrm{~km} / \mathrm{h}$.

The vertical sound velocity in the water column was recorded daily by a Valeport Sound Velocity Profiler (SVP) that recorded pressure, temperature and the sound velocity in the water column. Sound velocity depends on the temperature and the salinity of the water. The absolute depth accuracy depends on the correctness of the water velocity profiles, the motion sensor's capability to compensate for ship movements due to waves, positioning accuracy, the water depth and is in the range of centimeters (shallow waters) to a few decimeters (>50 m depth). Data were recorded using Kongsberg's SIS software and processed in HIPS/SIPS 10.4.13 software (University of Bern), then interpreted using ArcGIS 10.4.1.

\subsection{Seismic Acquisition}

The seismic profiles were acquired using a $3.5 \mathrm{kHz}$ system (Geopulse, Geoacoustic) in 2005 with a single-channel streamer (20 elements AE5000, GeoAcoustics) and an array of four sub-bottom profiling transducers (Mod. TR-1075A, Massa, USA) as receivers. Shot interval was 1 second. For navigation, a $3 \times 4 \mathrm{~m}$ UWITEC aluminum platform ("R/V Helga") equipped with four inflatable tubes for flotation and a $25 \mathrm{HP}$ outboard engine were used. The average speed of the vessel was $5 \mathrm{~km} / \mathrm{h}$. All $3.5 \mathrm{kHz}$ data were digitized (Octopus 360, Octopus Marine Systems, UK) and processed (15 to 5,000 Hz filtering) using Reflex software (Sandmeier Software, Germany). All profiles were interpreted using IHS Markit ${ }^{\circledR}$ Kingdom $^{-}$ v.2015.

\subsection{Coring and Lithological Description}

Five short cores (registered in the French national cyber-core-repository https://www.cybercarotheque.fr and the open international database www.geosamples.org as IZN19_03 [1.37 m; IGSN: TOAE0000000310], IZN19_04 [1.60 m; IGSN: TOAE0000000311], IZN19_16 [1.25 m; IGSN: TOAE0000000322], IZN19_21 [2.70 m; IGSN: TOAE0000000297], and IZN19_31 [2.79 m; IGSN: TOAE0000000307]) were collected from Lake Iznik in April and July 2019, using a UWITEC gravity corer with hammering. The cores were sampled on strategic points, depending on the first bathymetric and seismic results. In the laboratory, the cores were split into two halves. Each core was photographed after oxidation and a detailed sedimentological description was performed. The lithological description of the sequences allowed the identification of different sedimentary structures and facies, which were then correlated between the cores. Colors were assigned according the Munsell's color chart (Munsell Color, 1994).

\subsection{Sedimentological Analysis}

3.4.1. Grain-Size Analysis

The grain-size distribution of the sediment was determined following a mean of $5 \mathrm{~cm}$ sampling step all along the longest sequence (IZN19_21; Figure 3 for location). As the sequence contains sporadic mm thick sandy deposits, the resolution in these parts was increased to $0.5 \mathrm{~cm}$. A Beckman Coulter Life Science 13230 XR laser particle-size analyzer was used (EDYTEM Laboratory, University Savoie Mont Blanc) with sonication to avoid particle flocculation. Two runs with a $30 \mathrm{~s}$ long measurement were applied for each 


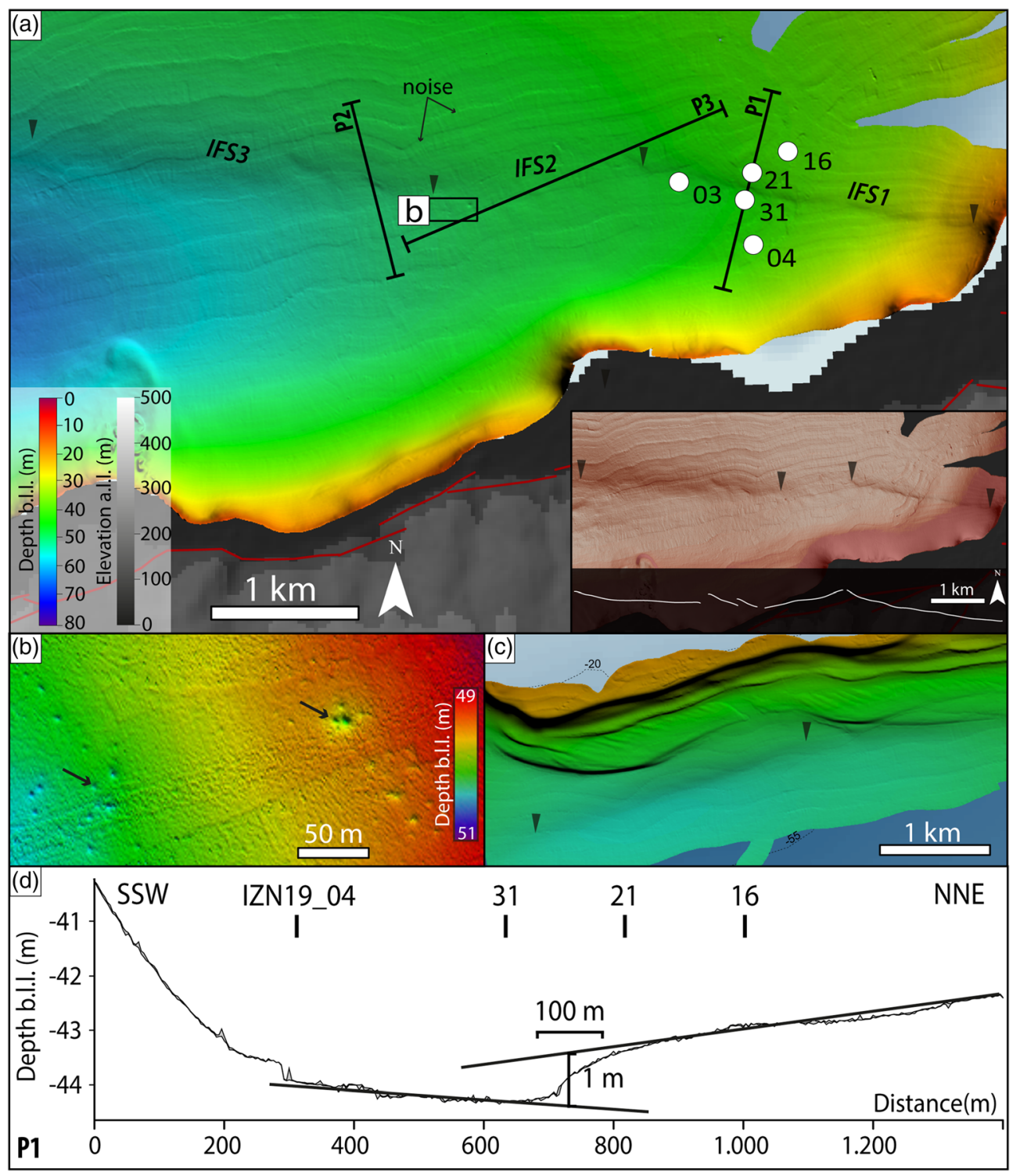

Figure 3. (a) Hillshaded bathymetric map ( $5 \mathrm{~m}$ grid) of the southeastern part of the lake (Figure 2 for location). A vertical exaggeration (ve $=20)$ is applied to highlight the Iznik Fault trace. The black arrows denote the extremities of the different visible segments of the Iznik Fault, termed as IFS1, IFS2 and IFS3 from east to west. White dots represent the core locations (IZN19_03, 04, 31, 21, 16). Black lines indicate topographic P1 (Figure 3d) and seismic section locations (P2 and P3; Figure 4). Subaerial elevation is derived from the SRTM model (1 arc-second resolution). The bathymetric and topographic scales are relative to the lake level, below and above (denoted as b.l.1. and a.1.1, respectively). Active faults ashore are shown in red (Benjelloun, 2017; Emre et al., 2018). Inset is an overlay of hillshade and slope maps to emphasize the fault traces. Black arrows indicated the termination of IFS1 and IFS3. In the lower part, an interpretative sketch of the fault geometry is shown. (b) Zoom of the pockmarks along the fault, indicating fluid escapes ( $1 \mathrm{~m}$ grid; ve $=10)$. Location is shown as a black rectangle in the main figure. (c) Hillshaded bathymetric map of the northern basin, showing the northern lineament, limited by the black arrows ( $5 \mathrm{~m}$ grid; ve $=10$; Figure 2 for location). (d) Topographic profile P1 derived from the bathymetric data, with a $2 \mathrm{~m}$ horizontal resolution and consists of two lines, the min-max values. Core locations are indicating above the profile (IZN19_04, IZN19_31, IZN19_21, and IZN19_16). The fault is characterized by an $\sim 1 \mathrm{~m}$ step on an $~ 100 \mathrm{~m}$ wide area. Hillshaded maps (a-c) have a Sun angle/elevation illumination of $20^{\circ} \mathrm{N} / 45^{\circ}$. Ve increases the noise in the data especially the swath traces.

fresh sample. Results of the grain-size distribution were processed with MATLAB R2016b software and presented in a contour plot with a color scale according to the abundance of particles in percentage for each grain-size class. 
Table 1

Radiocarbon Ages for the Lake Iznik Sediment Cores, in Bold the Rejected Age for Age Model Computation

\begin{tabular}{lccccc}
\hline Sample name & Core & MCD $(\mathrm{cm})$ & Radiocarbon age (yr BP) & Age cal BCE/CE 2 $\sigma$ range & Sample type \\
\hline Poz-118626 & IZN19_03 & 68 & $1170 \pm 35$ & 772-977 CE & Plant remains \\
Poz-118628 & IZN19_03 & 122.5 & $1555 \pm 30$ & 429-579 CE & Plant remains \\
Poz-118629 & IZN19_03 & $\mathbf{1 3 6}$ & $\mathbf{1 4 6 0} \pm \mathbf{2 3 0}$ & $\mathbf{6 3 - 1 0 3 2}$ CE & Plant remains \\
Poz-118561 & IZN19_16 & 68.3 & $1205 \pm 30$ & 704-941 CE & Plant remains \\
Poz-118973 & IZN19_21 & 70.5 & $1345 \pm 30$ & 643-775 CE & Plant remains \\
Poz-118627 & IZN19_21 & 245.5 & $2385 \pm 30$ & 719-393 BCE & Plant remains \\
Poz-118972 & IZN19_31 & 82.7 & $1015 \pm 30$ & $987-1153$ CE & Plant remains \\
Poz-118562 & IZN19_31 & 97.8 & $1070 \pm 30$ & 893-1026 CE & Plant remains \\
Poz-118563 & IZN19_31 & $\mathbf{2 2 9}$ & $\mathbf{1 7 0 0} \pm \mathbf{3 0}$ & $\mathbf{2 5 4}$ CE & Plant remains \\
Poz-118570 & IZN19_31 & 273.5 & $1820 \pm 30$ & 130-326 CE & Plant remains \\
Poz-122240 & IZN19_04 & 93 & $515 \pm 30$ & 1328-1447 CE & Plant remains \\
\hline
\end{tabular}

Note. BP denotes before present, that is, before $1950 \mathrm{CE}$. MCD denotes master composite depth.

\subsubsection{Scanning Electron Microscopy (SEM) and Energy-Dispersive Spectroscopy (EDS)}

To complete the core description, a representative $8 \mathrm{~cm}$ long slab including two coarser-grained deposits was resin-embedded to make $1 \mathrm{~mm}$ thick thin sections of the sediment, which were analyzed with a Vega3 Tescan Scanning Electron Microscope (ISTerre Laboratory, University Grenoble Alpes) following covering with a graphite layer of $20 \mathrm{~nm}$. Representative areas of the thin section were additionally analyzed with an Energy-Dispersive Spectroscopy (EDS) probe (Rayspec with SamX's electronic system and software, ISTerre Laboratory) to examine the elementary composition and to map chemical elements on specific lamina.

\subsubsection{Loss on Ignition}

The loss on ignition (LOI) analysis was performed on the IZN19_31 sequence (Figure 3 for location), with a $10 \mathrm{~cm}$ sampling interval all along the sequence to estimate organic matter $(\mathrm{OM})$ and carbonate proportion in the sediment, following the protocol described by Heiri et al. (2001).

\subsection{Geochemistry}

The relative contents of major and trace elements were analyzed with an X-Ray fluorescence (XRF) at $1 \mathrm{~mm}$ resolution on the surface of each sediment core with an Avaatech Core Scanner (EDYTEM Laboratory). The split core surface was first covered with a $4 \mu \mathrm{m}$ thick Ultralene film to avoid contamination and desiccation of the sediment. Element intensities are expressed in counts per second (cps). Different settings were used with $10 \mathrm{kV}$ and $0.2 \mathrm{~mA}$ during $15 \mathrm{~s}$ to detect $\mathrm{Al}, \mathrm{Si}, \mathrm{S}, \mathrm{K}, \mathrm{Ca}$, and Ti and at $30 \mathrm{kV}$ and $0.3 \mathrm{~mA}$ during $20 \mathrm{~s}$ for $\mathrm{Mn}, \mathrm{Fe}, \mathrm{Ni}, \mathrm{Cu}, \mathrm{Zn}, \mathrm{Br}, \mathrm{Rb}, \mathrm{Sr}, \mathrm{Zr}$, and $\mathrm{Pb}$ (Richter et al., 2006). A Principal Component Analysis (PCA) was performed on the geochemical results using R software Version 3.5.1 (R Core Team, 2018) to determine correlations between the different measured elements and to identify principal sediment endmembers, which are used to better constrain each sedimentological facies (e.g., Sabatier et al., 2010).

\subsection{Chronology of the Cores}

Eleven ${ }^{14} \mathrm{C}$ analyses of 11 organic plant macro remains were performed by accelerator mass spectrometer (AMS) at the Poznan Radiocarbon Laboratory. The ${ }^{14} \mathrm{C}$ ages were calibrated using the Intcal20 calibration curve (Reimer et al., 2020). Calibrated ages are expressed in the Common Era (CE) timescale: years before the $\mathrm{CE}$ are denoted $\mathrm{BCE}$ (Table 1). The age model and the sedimentation rate were calculated using the $\mathrm{R}$ code package clam (Blaauw, 2010). The best fit was obtained by applying a smooth spline model with 0.35 and 0.40 for the smooth parameter (for IZN19_21 and IZN19_31 cores, respectively).

\section{Results}

\subsection{Lake Bathymetry}

One third of the surface area of Lake Iznik $\left(\sim 80.5 \mathrm{~km}^{2}\right)$ was mapped in high-resolution (Figure 2a). Two prominent lineaments were discovered on the bathymetric data. One is located to the north, parallel to the onshore Boyalıca Fault and strikes NE-SW. This lineament separates the northern sub-basin and the shoreward underwater terraces (Figure 3c). 


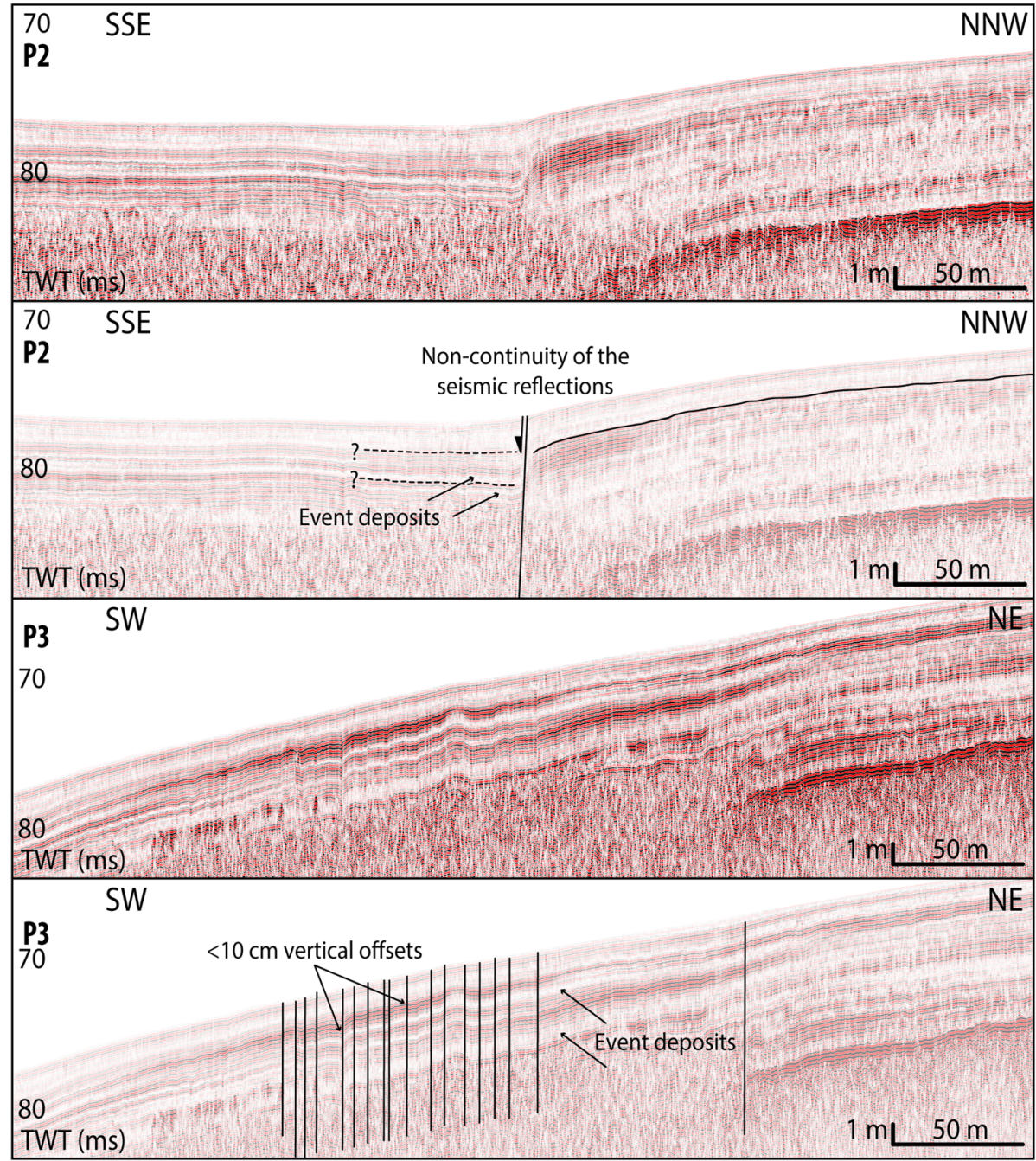

Figure 4. The $3.5 \mathrm{kHz}$ single-channel Pinger seismic profiles P2 and P3 (locations in Figure 3a). A raw and an interpreted version is presented for each profile.

The other lineament, striking NW-SE, has been discovered on the southeastern part and mapped over a distance of $9 \mathrm{~km}$ (Figure 3a). It separates the southern sub-basin from the central ridge (Figure 2) in the middle of the lake. This lineament presents two kinks separating it into three segments: IFS1, IFS2, and IFS3 (Figure 3a). IFS1 and IFS3 are $\sim 3 \mathrm{~km}$ length (Figure 3a). The bathymetric profile perpendicular to the IFS1 shows an $\sim 1 \mathrm{~m}$ vertical offset of the lake floor (profile P1; Figure 3d), extending over a distance of $\sim 100 \mathrm{~m}$. These segments are linked by IFS2 those scarp is barely visible on the bathymetric data (Figure 3a). Furthermore, numerous pockmarks are visible along the fault trace at the transition from IFS2 to IFS3, indicating fluid escapes (Figure 3b). The size of these depressions varies from few centimeters to $6 \mathrm{~m}$ diameter and reaches $\sim 60 \mathrm{~cm}$ deep (Figure 3d). Where the lineament extends ashore, it merges into the main branch of the MNAF, close to the village of Dirazali. However, the surface expression of the fault is masked by human activity, mainly due to fields of olive and fruit trees. According to these observations, we interpreted this lineament as a fault, termed Iznik Fault.

\subsection{Seismic Reflection Data}

High-resolution seismic profiles were acquired across IFS2 and IFS3 (Figure 3a). These single-channel reflection sections show maximum acoustic penetration of $\sim 10 \mathrm{~ms}$ two-way travel time or $\sim 7.5 \mathrm{~m}$ (assuming acoustic velocities of $1,500 \mathrm{~m} / \mathrm{s}$ ), after which signals become weaker and difficult to interpret due to high gas content of the sediment. Chaotic-to-transparent acoustic seismic facies is interpreted as turbidite deposits or 


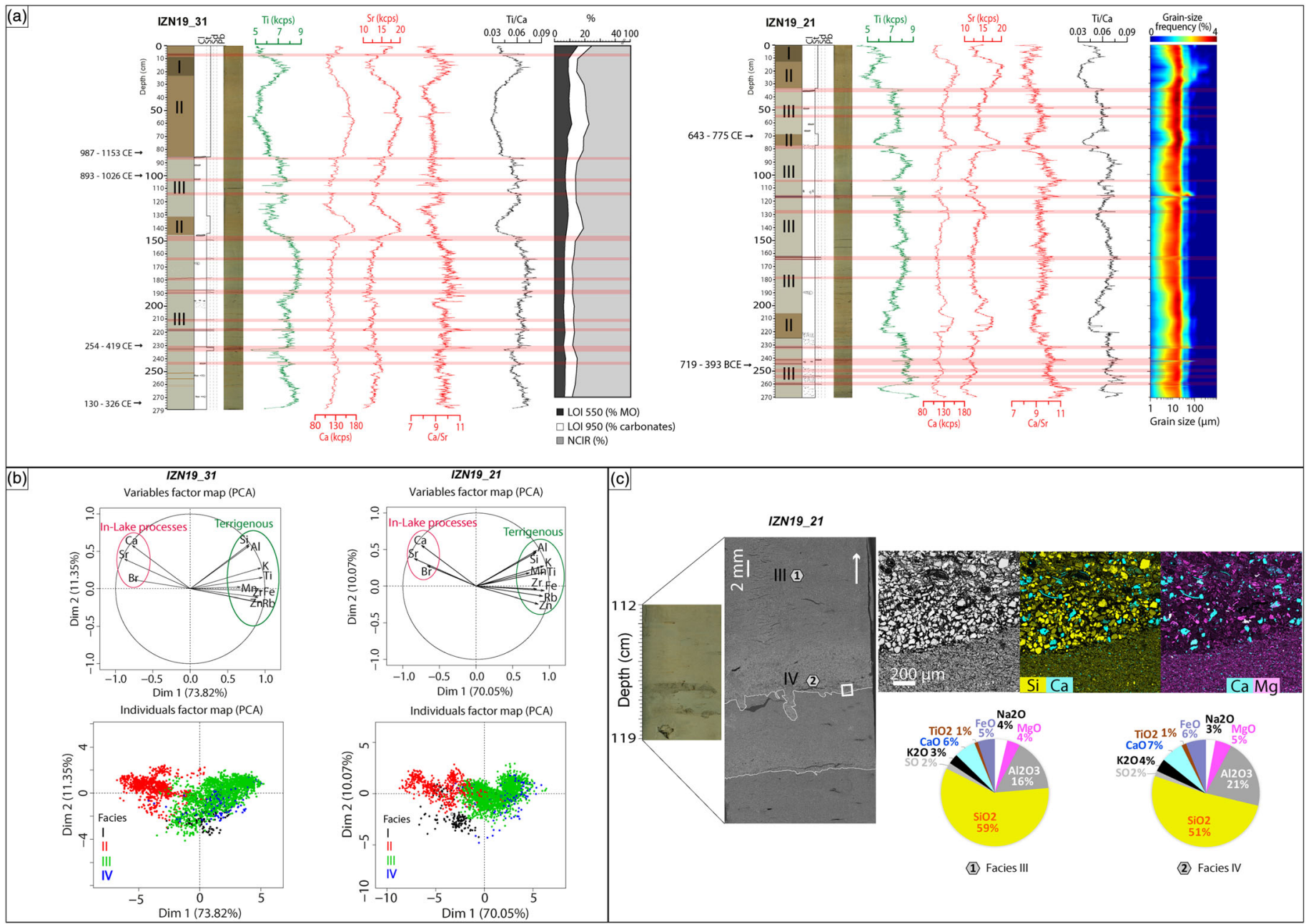

Figure 5. Main sedimentological and geochemical results of IZN19_31 and IZN19_21 cores. (a) Macroscopic description, photography, XRF data (Ti, Ca, Sr, $\mathrm{Ca} / \mathrm{Sr}$, and $\mathrm{Ti} / \mathrm{Ca}$ ). Ia, Ib, and II denote the different facies types, sandy event deposits (Facies IV) are displayed in red. $\mathrm{Cl}, \mathrm{St}, \mathrm{Sd}$, and $\mathrm{Pb}$ abbreviations refer to the grain size observations: clay, silt, sand, and pebble, respectively. The LOI results are presented for the Core IZN19_31 while the grain-size contour plot is displayed for the Core IZN19_21 (b) PCA for cores IZN19_31 and IZN19_21. The respective variables factor maps show that two end-members are defined, one representing the in-lake processes and one corresponding to the terrigenous inputs. The individual factor maps show the correlations of each facies type with the different end members. (c) Detailed coupled SEM/EDS analysis of Facies III versus Facies IV. Optical and SEM photos (left), geochemical mapping (right) show the relative abundance of major elements ( $\mathrm{Si}, \mathrm{Ca}$, and $\mathrm{Mg}$ ) within the area studied (white box on the SEM photography). The relative oxide compositions between Facies III and IV are shown below.

mass-movement deposits indicating a slope failure at the location of IFS3 on the seismic section supporting the fault nature of the lineament and its location (Profile P2; Figure 4) (e.g., Cukur et al., 2013). Although it is difficult to assess the vertical offset on the different seismic profiles, the continuity of the seismic reflections is affected across the fault. The second seismic section parallel to IFS2 (Profile P3; Figure 4) does not show any clear slope failure but only slight vertical offsets of the seismic reflections and a series of closely spaced incipient faults displacing steeply the uppermost meters of sediment.

\subsection{Sedimentary Sequences}

\subsubsection{Sedimentary Facies}

Lake Iznik sediments consist mainly of clays and silts (Roeser et al., 2012; Figure 5). In the here investigated short cores, very fine to fine sand laminae appear very sporadically at the millimeter scale in the finer matrix of background deposits. Based on macroscopic observations and confirmed by geochemical analysis, four main lithological facies were identified. 
1. Facies I is composed of brown $(5 \mathrm{Y} / 4 / 4)$ silt $(\mathrm{D} 50=10 \mu \mathrm{m})$ and occurs at the top of each core. The organic proportion (LOI550) of this facies amounts to $~ 9 \%$ and the carbonate proportion (LOI950) to $6 \%$.

2. Facies II occurs at different depths in the sequences and consists of slightly coarser light brown $(2.5 \mathrm{Y} / 5 / 4)$ silt $(\mathrm{D} 50=15 \mu \mathrm{m})$. Facies II has the highest proportion of organic matter $(\sim 10 \%)$ and carbonate $(\sim 10 \%)$.

3. The majority of the sedimentary sequence consists of Facies III, which is a more heterogeneous facies with olive gray color $(5 \mathrm{Y} / 6 / 2)$ clayey silt $(\mathrm{D} 50=8 \mu \mathrm{m})$. This facies is interrupted by a total of 15 and 18 few $\mathrm{mm}$ thick (max $2 \mathrm{~cm}$ thick) silt (to sandy) laminae in cores IZN19_31 and IZN19_21, respectively, denoted as Facies IV and termed "event deposits" (D50 $=20 \mu \mathrm{m}$ in general). This facies shows the lowest proportion in organic matter $(\sim 7 \%)$ and carbonates $(\sim 7 \%)$. Nevertheless, LOI values do not vary much over the entire sequence. The fraction of non-carbonate ignition residue (NCIR) is higher than $80 \%$ for the whole sequence (Figure 5a). All event deposits appear to the naked eye as mm thick levels of very fine sand or silty lenses within the continuous sedimentation of Facies III. The detailed SEM observations show that these sandy laminae have an erosive base incising into clayey sediments and a fining-upward trend. Bioturbation with vertical burrows is present throughout their base. Burrow length varies from 1 to $4 \mathrm{~mm}$, and they are filled with particles to the overlying laminae (Figure 5c). Moreover, a comparison of the oxide composition of two event deposits compared to the background sedimentation has been performed with the EDS sensor (Figure 5c). These maps show that Facies III and IV have the same major element compositions and that all carbonates within the Facies IV are sometimes composed by $\mathrm{Ca}$ and $\mathrm{Mg}$ and reach $50 \mu \mathrm{m}$ (Figure 5c). Facies IV laminae are thus distinct from Facies III due to their fining-upward trends, their erosive base and the coarse-grained $\mathrm{Ca} /$ low-Mg-carbonates (Figure 5).

\subsubsection{Geochemistry}

PCA was conducted on the XRF geochemical data of both IZN19_31 and IZN19_21 cores located on both sides of the fault (Figure 5b). Dimensions 1 and 2 (denoted as Dim 1 and Dim 2) explain $85.17 \%$ and $80.12 \%$ of the total variability for IZN19_31 and IZN19_21 cores, respectively. From the variables factor map, two end-members could be identified. The first one, denoted as "terrigenous," shows high positive loadings with Dim 1 (e.g., $\mathrm{Al}, \mathrm{Si}, \mathrm{Ti}, \mathrm{K}$, and $\mathrm{Rb}$; in green in Figures 5a and 5b). The second end-member is interpreted as "in-lake processes" (Ca, Sr, and $\mathrm{Br}$ ). It displays negative loadings on Dim 1 and positive loadings on Dim 2 (red in Figures 5a and 5b). We link it to the endogenic carbonate production and organic matter (Guevara et al., 2019). The individual factor map highlights the characteristics of each facies. Facies II is dominated by the endogenic process end-member, which correspond the higher LOI550 values (Figure 5b). In contrast, Facies III is influenced by terrigenous input. Facies I is in an intermediate position with relatively higher Ti counts than Facies II (Figure 5a). Facies IV shows a similar geochemical characteristic and are nearly always occurring within the Facies III (Figure 5c).

\subsubsection{Core-to-Core Correlation}

On the basis of the lithological description and XRF measurements, a correlation between the cores across the Iznik Fault is proposed (Figure 6). The IZN19_03 Core has been excluded from the comparison to limit uncertainties because of its distance to this transect (IZN19_03 Core is presented Figure S1 in the supporting information). In Figure 6, the Dim 1 (terrigenous supply vs. in-lake processes) and the Ca signal are displayed to highlight the stratigraphic units' correlation. Five different stratigraphic units (from top to bottom: purple, green, orange, dark blue, and gray) were correlated on the P1 profile across IFS1 (Figure 3d). Thickness of these units varies significantly, particularly between cores in the immediate vicinity of the fault, IZN19_31 on the hanging wall and IZN19_21 on the footwall of the fault. Based on the stratigraphic correlation, it was possible to correlate the radiocarbon dates (Table 1) to IZN19_21 and IZN19_31 cores and use all of them for age modeling.

\subsection{Radiocarbon Dating and Age Models}

Eleven organic terrestrial plant macroremains were dated (Table 1) and stratigraphically correlated between cores IZN19_31 and IZN19_21. This allowed us to use all dates on both cores for age modeling (Figure 7). Both cores have almost the same length ( 279 and $270 \mathrm{~cm}$, respectively), and they were taken very close one to the other (200 $\mathrm{m}$ apart) on each side of the fault. The core located north of the fault (IZN19_21) spans a larger period of time and reach at the base $\sim 640 \mathrm{cal}$. BCE, whereas the core south of the fault (IZN19_31) encompasses a shorter time period with the base reaching 210 cal. CE. These different basal ages clearly document the higher sedimentation rates south of the faults. Core IZN19_31 shows more pronounced variations in the sedimentation rate, and four periods can be differentiated (Figure 7). (1) A period with a 


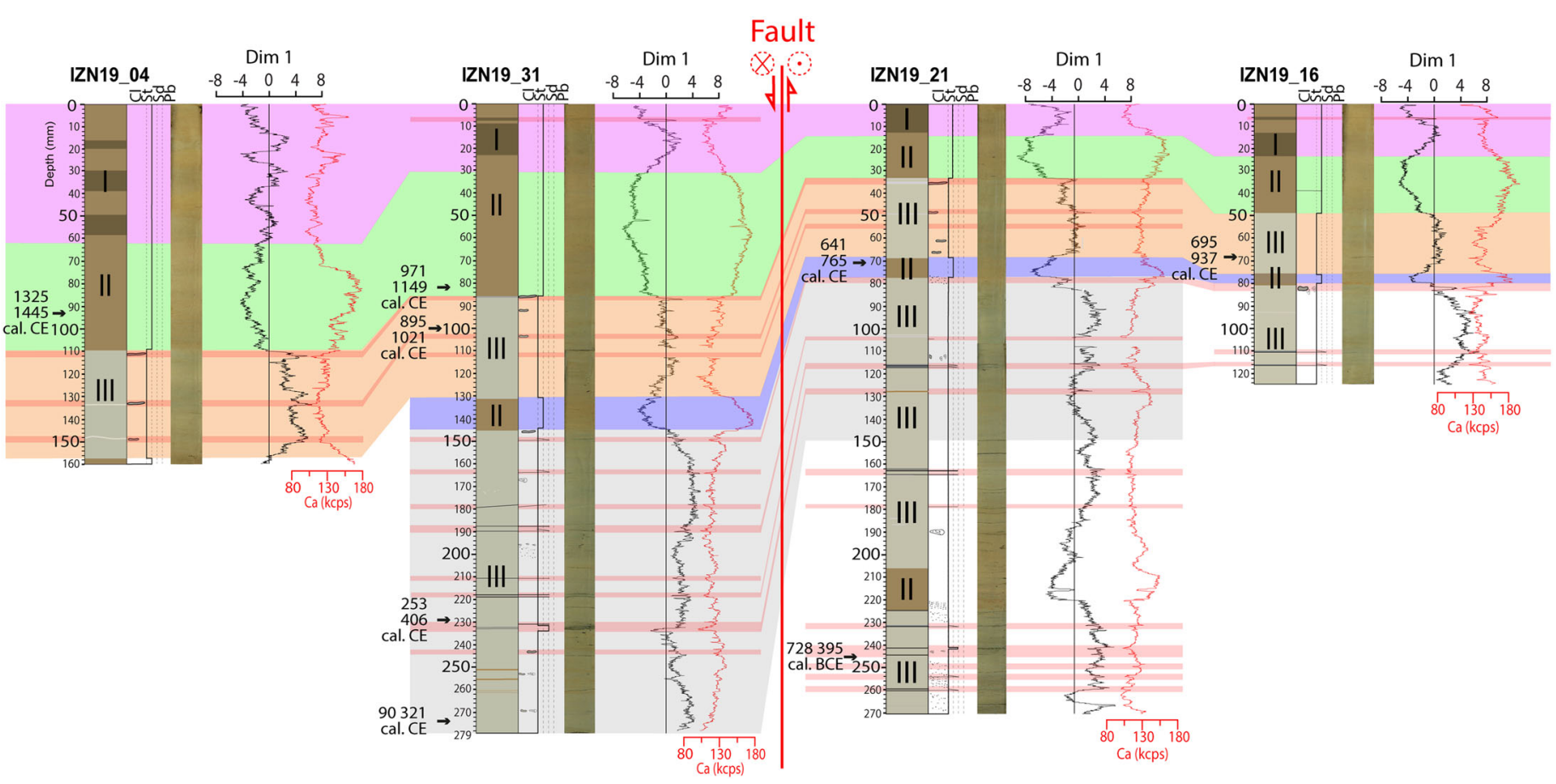

Figure 6. Core-to-core correlation of the transect across IFS1 (Figure 3a). Topography is neglected. For each core: lithological description, photography, Dim 1, and Ca signal are displayed. The different colors represent five stratigraphic units. Event deposits are shown in red. Individual radiocarbon dates are shown with black arrows (Table 1 for details). I, II, and III represent the names of the different facies types defined in the text.

relatively high sedimentation rate from 200 to 350 cal. CE. During this period, the sedimentation rate is almost constant ( $\sim 1.8 \mathrm{~mm} / \mathrm{yr})$. (2) The sedimentation rate show a significant increase from 350 to $600 \mathrm{cal}$. CE reaching $5.6 \mathrm{~mm} / \mathrm{yr}$. (3) The sedimentation rate decrease at $0.7 \mathrm{~mm} / \mathrm{yr}$ around 1,300 cal. CE. And (4) sedimentation rate increases from $1,300 \mathrm{cal}$. CE until the modern period ( $1.1 \mathrm{~mm} / \mathrm{yr}$ at the top). Core IZN19_21 shows almost the same trends, but with less pronounced variations (Figure 7).

\section{Discussion}

\subsection{Event Deposits Versus Seismic Historical Archives}

The LOI analysis of the cores shows that almost $80 \%$ of the whole sediment sequences are composed of terrigenous siliciclastic constituents (Figure 5a), whereas the in-lake carbonate production represents only a minor fraction. Roeser et al. (2016) and Roeser (2014) showed that Sr is strongly correlate to aragonite, which is closely linked to endogenic precipitation in Lake Iznik's water. In contrast, calcite is linked to both endogenic and detrital input. The terrigenous component is expressed by high Ti counts, which are characteristic of siliciclastic and felsic volcanic rocks in the southern part of the catchment (Figures 2a, 5a, and 5b). Our study reveals evidence for multiple thin Ti-rich sandy normally graded laminae termed event deposits (Facies IV in Figure 5). The turbidites are defined by their lithological and textural characteristics. They show fining-upward patterns and a higher content of terrigenous elements as indicated by the Ti/Ca ratio and the PCA (Figures 5a and 5b). Moreover, they show higher values of detrital carbonates shown by the $\mathrm{Ca} / \mathrm{Sr}$ ratio and the presence of low-Mg coarse-grained carbonates (Figures 5a and 5c).

Turbidites can be triggered by several processes such as hyperpycnal flows related to river flooding (e.g., Wilhelm et al., 2015), remobilization of superficial lacustrine slope sediments due to seismically induced subaquatic failures of lateral slopes (e.g., Hage et al., 2017; Schnellmann et al., 2005), or spontaneous slope failures due to high surcharge in sediments of submerged delta slopes (e.g., Girardclos et al., 2007; Hilbe \& Anselmetti, 2014). The last hypothesis is less probable as slope angles are gentle in this area (less than $5^{\circ}$ ), which significantly reduces the probability of such spontaneous slope failures (Schnellmann et al., 2005). Turbidites are getting thinner from SW to NE (Figure 6) and some of these deposits are 

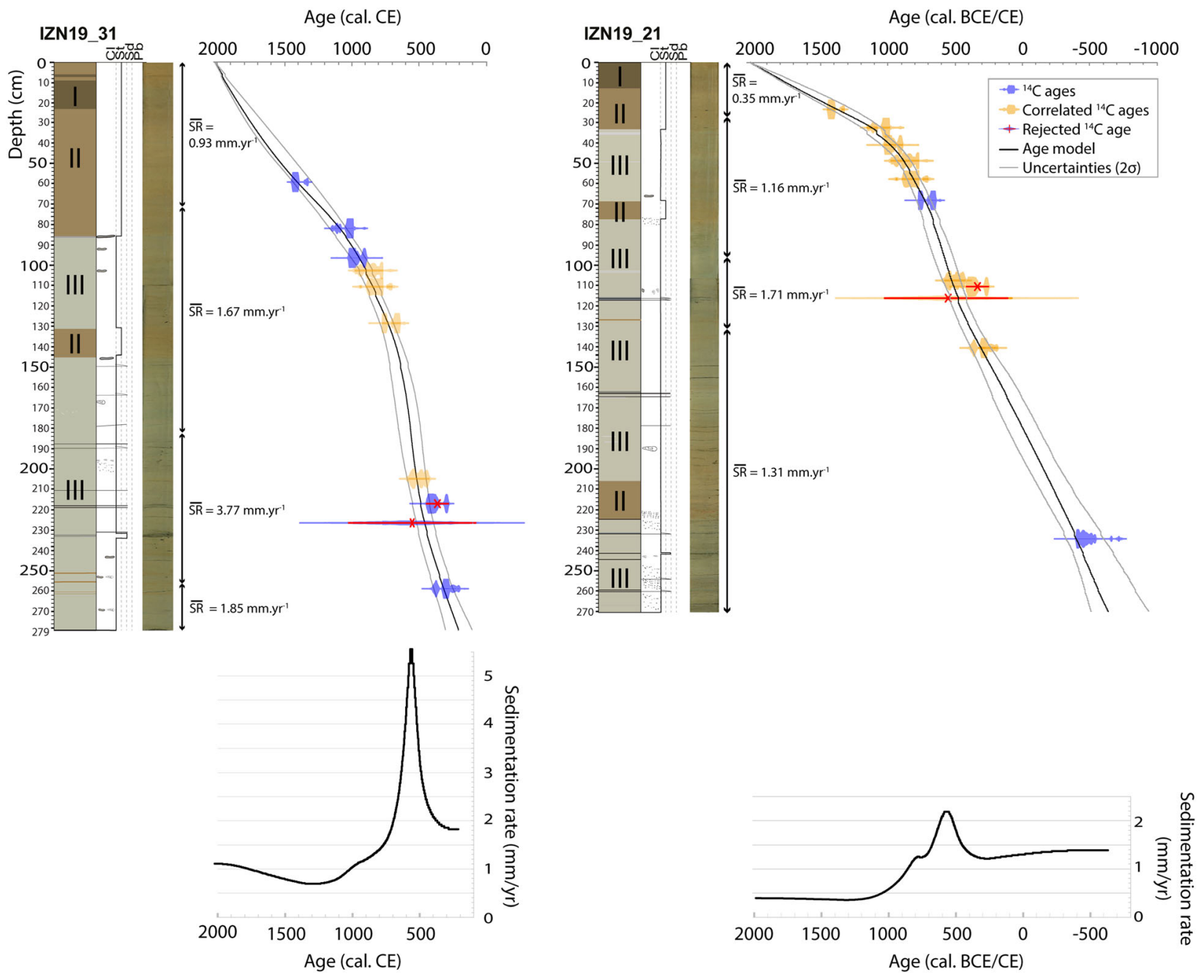

Figure 7. Lithological description, photography, age model for cores IZN19_31 and IZN19_21 and their respective sedimentation rate variation curve through time. The age models are computed with Clam R package (Blaauw, 2010) using the radiocarbon data (Table 1). The blue dates origin in the displayed core itself; the orange radiocarbon ages are those which are correlated from other sequences (Figure 6). One radiocarbon age has been rejected for the age model computation due to its large uncertainty (marked in red, details in Table 1). SR denotes the average sedimentation rate within a given period (refer to the text for details).

absent in Core IZN19_16, which is farther away from the closest significantly sediment contributing delta (Figure 3a). The frequency of these turbidites and in particular the fact that no deposit has been observed over the last 1,000 years is difficult to explain with the "flood hypothesis.". However, given the active tectonic context of the region, it is plausible that such turbidites are related to shallow slope destabilizations by recurrent earthquakes, as previously proposed for thin turbidites in a similar context of Lake Hazar ( $900 \mathrm{~km}$ southeastward on the East Anatolian Fault; Hage et al., 2017; Hubert-Ferrari et al., 2020). To evaluate this potential seismic cause, the age of the turbidites, deduced from age models of cores IZN19_21 and IZN19_31 are compared with those of the historical earthquakes in a broader area (Ambraseys \& Finkel, 1991; Ambraseys \& Jackson, 2000; Ambraseys, 2002, 2009; Guidoboni \& Comastri, 2005; Tables S1 and S2 in the supporting information). The sensitivity of Lake Iznik to record regional earthquakes can be characterized by the Earthquake-Sensitivity Threshold Index (ESTI) (Wilhelm et al., 2016), for which the sedimentation rate is critical in controlling the ability of a lake system to record earthquake-induced deposits. The higher the sedimentation rate is, the greater the ESTI is and the more likely it is to record earthquakes. As the sedimentation rate changes through time 

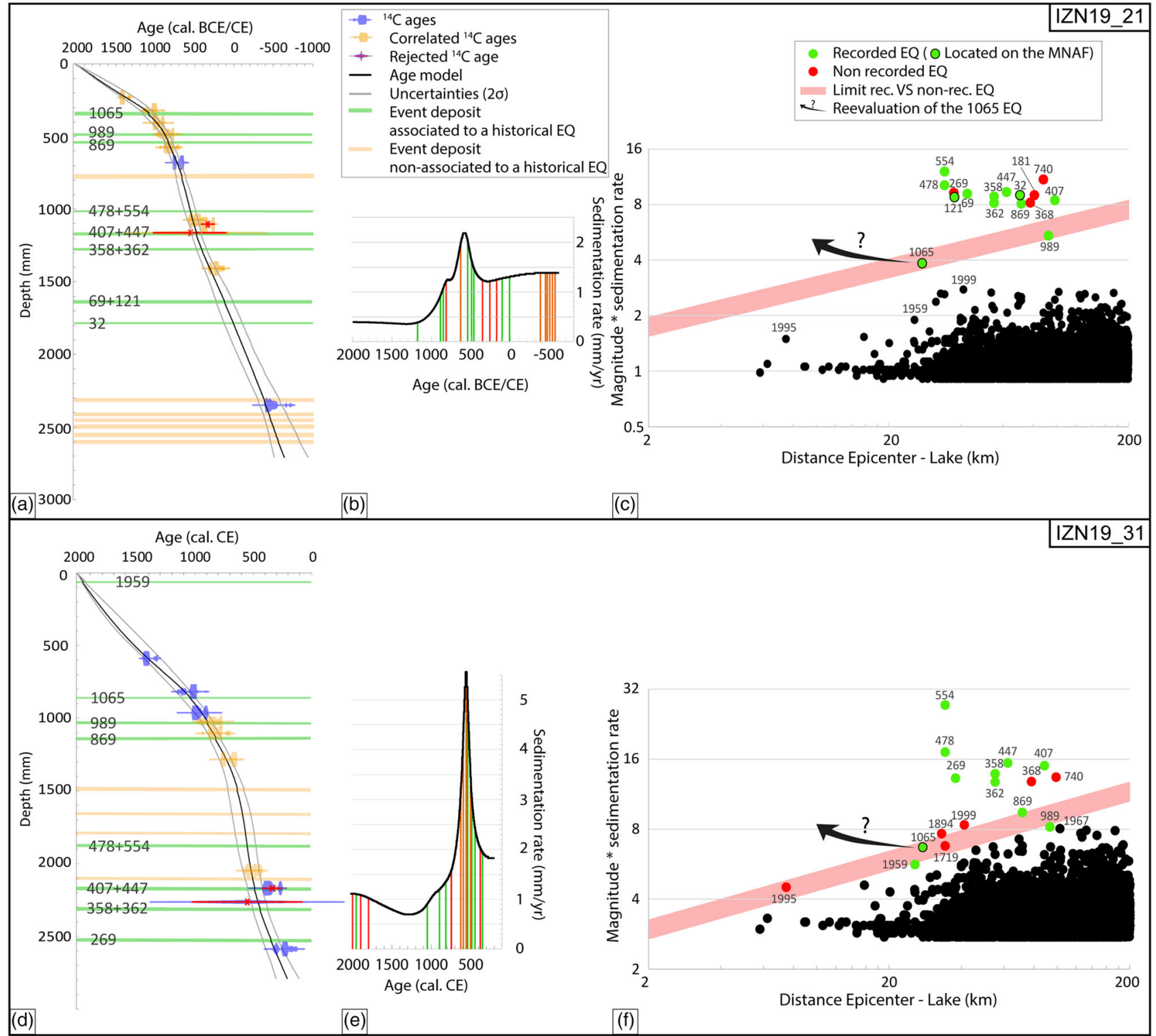

Figure 8. Diagrams displaying for cores IZN19_21 and IZN19_31 (a, d) the interpreted age models. (b, e) The sedimentation rate variations through time. The green lines represent the event deposits associated to an earthquake as opposed to the orange lines. Red lines represent times at which earthquakes happened without event deposit in the sediment cores. (c, f) Conceptual plots presenting the distance of earthquake epicenters to Lake Iznik ( $40.406^{\circ} \mathrm{N}, 29.673^{\circ} \mathrm{E}$ as reference) versus earthquake magnitudes multiplied by the sedimentation rate averaged over the previous 100 years. The red thick line delimits the best fit versus recorded and non-recorded earthquakes. Black dots represent earthquakes below the best fit line that are not recorded in the lake. The black arrows show where the $1065 \mathrm{CE}$ earthquake should be located in the diagram as the Iznik fault ruptured in the lake at that time (see below in the text).

(Figure 7), the ESTI of Lake Iznik might also have changed accordingly. A weighting of earthquake magnitudes by the sedimentation rate over 100 years prior to the event is performed, thus the relationship between the sedimentation rate and the turbidites occurrence is explored in Figure 8.

In Core IZN19_21 that spans a longer time period till 640 cal BCE, 19 distinct event deposits are observed. Six of them are older than $0 \mathrm{cal} C \mathrm{CE}$ and thus predate the first historical seismicity records for this area. For the 13 remaining sandy deposits, 12 historical earthquakes can be related to turbidite deposits (Figure 8 and Table S1 in the supporting information). The last event deposit, which have not been correlated with a historical earthquake is identified in the higher sedimentation rate period (350 to $600 \mathrm{cal} \mathrm{CE}$ ) probably related to enhanced erosion by intense human activities during Roman time (Arnaud et al., 2016; Bajard et al., 2017) 
such as agriculture as reflected in high amounts of olive tree pollens (Miebach et al., 2016). These fields were abandoned around $650 \mathrm{CE}$ when Pinus pollen increased (Miebach et al., 2016). This rise in the sedimentation rate explains the increased sensitivity of the lake to record ground shaking (Rapuc et al., 2018; Wilhelm et al., 2016). During such periods, the lake is prone to record earthquakes with significantly smaller magnitude, which might not be reported in historical accounts. We cannot exclude that the deposit could also be related to another triggering mechanism such as flood, considering that at least one flood is mentioned in a historical archive for that time period during the reign of Justinian (527-565 CE) (Evans, 2005).

In Core IZN19_31, 15 event deposits are described, all of them in the time span of historical accounts. Eleven are associated with earthquakes (Table $\mathrm{S} 1$ in the supporting information). The four others also appear in the high sedimentation rate period during which the lake sensitivity was high.

Overall, this approach shows conclusive results as 23 thin turbidites can be associated with earthquakes in both cores, corresponding to 14 independent earthquakes (Figure 8). Three of them correspond to earthquakes recorded on the MNAF segments (29-32, 121, and $1065 \mathrm{CE}$ ) (Figures 8c and 8f). In turn, some historically known earthquakes such as the 368 or $740 \mathrm{CE}$ that strongly damaged Iznik were not recorded in our sedimentary sequences. The $368 \mathrm{CE}$ may be preceded by two close older events. Two sandy deposits visible in Core IZN19_31 at $232 \mathrm{~cm}$ depth, respectively, $128 \mathrm{~cm}$ in IZN19_21 Core (Figure 5), could correspond to two of the three historical earthquakes known from that time: 358, 362, and $368 \mathrm{CE}$ (Table S2 in the supporting information). According to their distance to the lake and magnitude (Figures 8c and 8f), 358 and $362 \mathrm{CE}$ earthquakes, located on the NNAF at $\sim 40 \mathrm{~km}$ from Lake Iznik (Ambraseys, 2002), are supposed to be recorded as they are up to the threshold. Hence, the $358 \mathrm{CE}$ earthquake, recorded in the Gulf of Izmit (Çağatay et al., 2012), could have been recorded as a thick deposit $(2 \mathrm{~cm}$, i.e., more than four times thicker than all other event deposits). The overlying thinnest coarse-grained laminae could corresponds to the 362 CE earthquake but it was never recorded in the Marmara Sea (Çağatay et al., 2012; Drab et al., 2015; McHugh et al., 2014; Yakupoğlu et al., 2019). The lack of a third deposit marking the $368 \mathrm{CE}$ earthquake thus likely indicates that the slopes did not have enough time to replenish the re-mobilizable sediment stock to form a new turbiditic deposit within only a few years after two earlier earthquakes. Another explanation is that the $362 \mathrm{CE}$ has not been recorded, or its related-turbidite could have been eroded by the one of the 368 CE earthquake, in particular, since historical data (e.g., Guidoboni et al., 1994) indicate that Iznik was mostly destroyed during the earthquake of $368 \mathrm{CE}$. Uncertainties still remain for the assignments of historical events during this period, more data are needed in the lake to document this point.

Furthermore, Iznik was highly damaged or destroyed by other events in 29-32, 740, and 1065 CE with earthquake magnitudes estimated between 6.8 and 7.2 (Ambraseys, 2002). These magnitudes were calculated from the spatial distribution of intensities around the maximum intensity zone (Ambraseys, 2002), which in turn were estimated from historical accounts. Hence, variable population, changes in building vulnerability over time, and exaggeration in the historical sources are difficulties affecting these estimations.

The 740 CE earthquake has been documented in several places within the Marmara Sea (e.g., Çağatay et al., 2012; Drab et al., 2015; McHugh et al., 2014; Yakupoğlu et al., 2019), as the epicenter is supposed to be located on the NNAF (Ambraseys, 2002). According to epicentral distance and to its magnitude (Figure 8), it should also be recorded in our sedimentary sequences. However, we could not find any evidence supporting it. McHugh et al. (2014) argue that seismo-turbidite cannot be triggered far from the ruptured segment. On the contrary, the $358 \mathrm{CE}$ earthquake that we recorded was only recorded in the eastern part of the Izmit Gulf (Çağatay et al., 2012) and not in the other Marmara Sea Basin (e.g., Yakupoğlu et al., 2019). The presumed location of the $358 \mathrm{CE}$ epicenter is near Izmit (Ambraseys, 2002).

Concerning the instrumental period, 8,500 earthquakes (from 1935 to 2019; Figures 8c and 8f) occurred in an area $200 \mathrm{~km}$ around Lake Iznik and with magnitudes (reported magnitude types vary) ranging from 2.5 to 7.6 (U.S. Geological Survey, USGS, catalogue; https://earthquake.usgs.gov/earthquakes/search/). Among these earthquakes, only the $1959 \mathrm{CE}$ event is close to the sensitivity threshold of the lake for Core IZN19_31, while it is below the detection limit for Core IZN19_21. Near the top of the Core IZN19_31, only one turbidite is observed, which could correspond to this earthquake (Figure 8d). However, four recent earthquakes $(1719,1894,1995$, and 1999) are not recorded in the sedimentary sequences, even though they are near the sensitivity threshold. However, there are likely many more variables affecting the detection limit and a sharp threshold is not expected in such a natural system (Figure 8f). 
Finally, if we consider the historical location and magnitude $(\mathrm{Ms}=6.8$ ) of the $1065 \mathrm{CE}$ earthquake, more than $20 \mathrm{~km}$ east of Iznik (Ambraseys, 2002), it should be below the detection limit of Lake Iznik and hence should not be recorded in our cores. Furthermore, it is not recorded in the Marmara Sea (e.g., Yakupoğlu et al., 2019). According to our study and the discussion below, we suggest a reconsideration of either its epicenter location or its magnitude.

The other events $(989,869,554,478,447$, and $407 \mathrm{CE})$ have been documented in the Kumburgaz Basin of the Marmara Sea; therefore, they could be related to NNAF ruptures (Yakupoğlu et al., 2019). The 989 and $478 \mathrm{CE}$ are also documented in the Çınarcık Basin (Drab et al., 2015).

The strong correlation between historical and instrumental recordings and our sedimentary records support the reliability of this conceptual approach. These results indicate that Lake Iznik's sediments record the past regional seismicity on the different branches of the NAF system. Upcoming studies should take into account sediment cores from different sub-basins of Lake Iznik. They will help to distinguish more accurately the source(s) of such coarser-grained deposits, their synchronicity in different independent locations being a strong argument for their seismic trigger (e.g., Van Daele et al., 2015).

\subsection{Discovery of Hitherto Unknown Subaquatic Faults}

The bathymetric survey carried out in the lake allows to identify two subaquatic faults (Figures 2 and 3). The first one is located in the northern sub-basin, striking SW-NE. It is characterized by a sharp vertical scarp of $\sim 5 \mathrm{~m}$ (Figure 3c), forming the northward edge of the northern sub-basin and the shoreward underwater terraces (Figures 2a and 3c). This fault segment runs parallel close and south to the Boyalica Fault so that we consider it is a segment of it. The terraces, with depths of 20,40, and $45 \mathrm{~m}$ b.1.1., interpreted as markers of past low lake levels as documented in the Gemlik Bay (Eriş et al., 2019) are offset by the fault. Microseismic data document a normal slightly dextral movement on this fault during a Ms 2 earthquake (Gurbuz et al., 2000) and previous seismic study described this fault as a dextral P-shear or secondary synthetic shear fault (Öztürk et al., 2009). Many SW-NE faults are observed at the regional scale (Figure 1), suggesting they are inherited structures. The kinematic of the South Boyalica Fault may have change thought time as suggested by the left-lateral shift of the shorelines along the South Boyalica Fault which gives a peanut shape to the lake.

The second fault identified in Lake Iznik, previously unknown—-termed Iznik Fault—strikes E-W and separates the southern sub-basin from the central ridge (Figure 2). The high-resolution seismic profile across IFS2 shows a series of steep faults interpreted to be arranged en echelon manner (Figure 4, Profile P3), suggesting that it presents mostly a strike-slip movement. The Iznik Fault seams to cross the entire lake; its eastern prolongation joins the dextral Dirazali Fault system onshore and potentially the dextral Gemlik Fault to the west (Figure 2), which would suggest a right-lateral component for this fault. Besides, the smaller en echelon faults on the border between IFS2 and IFS3 is related to small depressions, which (due to the fault orientation) indicate a right-lateral component. The vertical component of this fault is small as suggested by its small scarp (1 m).

These two subaquatic faults are most likely still active as expressed by the morphological step observed on the lake floor. The present activity of the Iznik Fault, in particular, is indicated by the change in sedimentation rate across the structure and the occurrence of many pock marks indicating fluid escape along the fault. Such fluid venting likely indicates by deep-seated pathways along the buried fault plane (Figure $3 b$ ).

\subsection{Identification of the Last Earthquake Rupture on the Iznik Fault}

The core-to-core correlation across the Iznik Fault (IFS1 on Figure 3a) allows to identify thicknesses variations of sedimentary units across the structure. For the present-day profile (Figure 9a), the topography is deduced from the multibeam bathymetry (Profile P1 on Figure 3a). From the sediment core analysis we retrieved the paleotopography and sedimentological features at different moments by removing unit by unit from the top to the bottom of the cores. For each depth, the age is determined from the age models of cores IZN19_21 and IZN19_31 (Figure 7); the total uncertainty range of the different ages allows to encompass the time span. After removing the pink and green units (Figure 9b), the residual topography is assumed to be the paleo topography at 1000/1154 cal. CE. Compaction and erosion are neglected on this reconstruction, as we suppose a similar effect on both sides of the fault as well as similar erosional processes (e.g., deep currents). This reconstruction highlights a sediment thickness variation of $\sim 40 \mathrm{~cm}$ between the hanging and the 


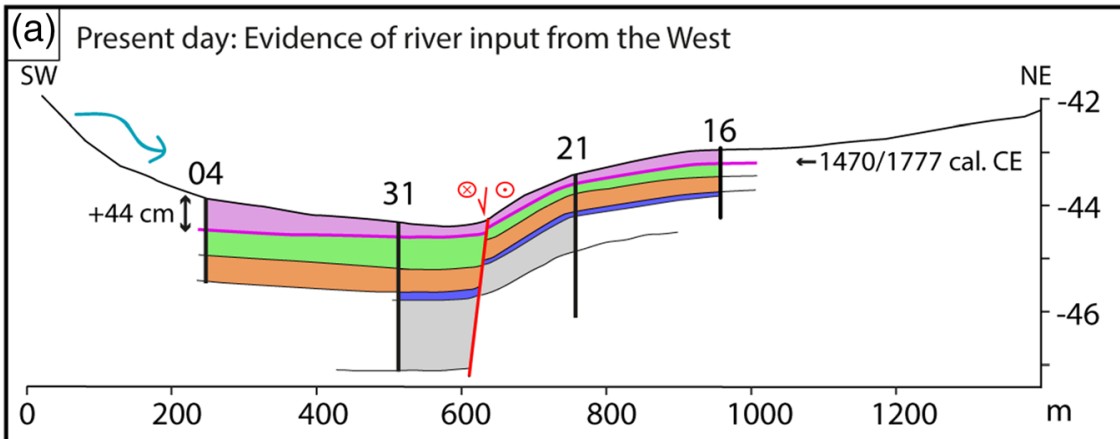

(b) 1010/1182 cal. CE: Evidence of a vertical offset of the fault

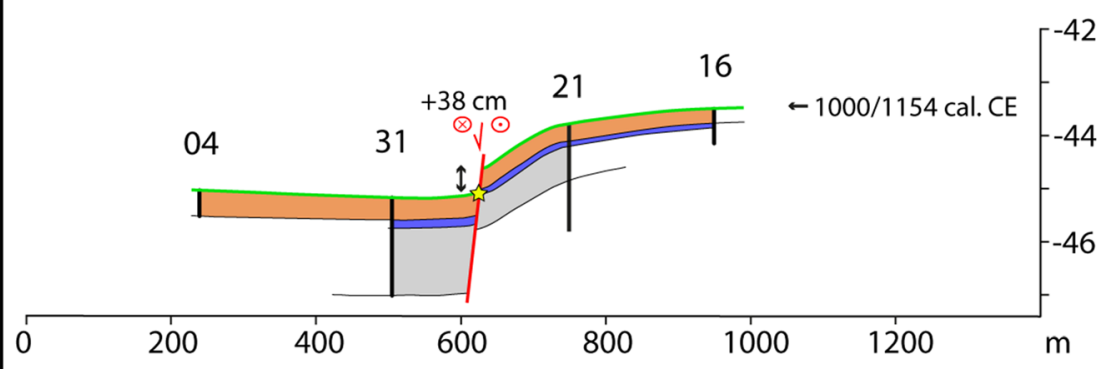

(c) Before the fault rupture: longer cores are needed to define the base of the grey layer

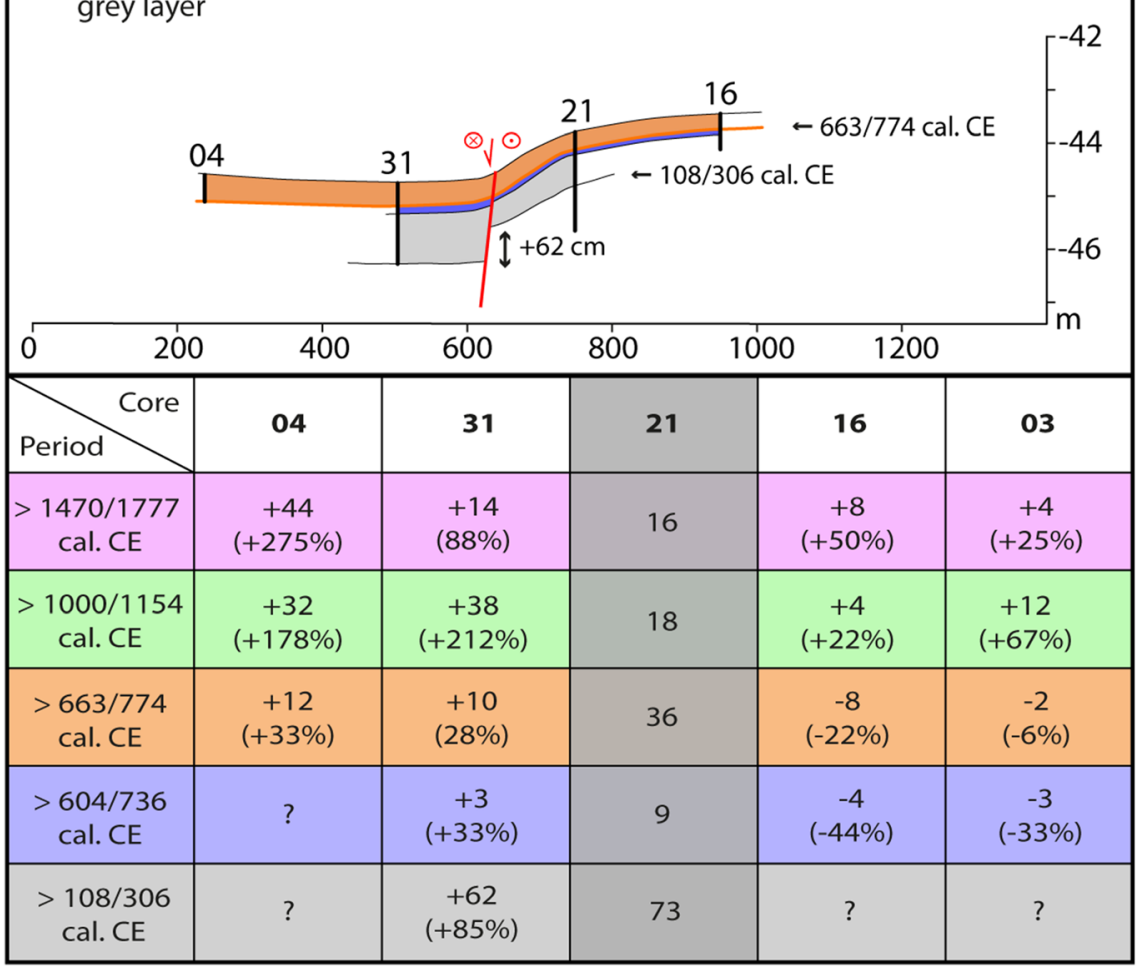

Figure 9. Conceptual diagrams presenting the (paleo)topography and sedimentological reconstructions at three different times. The location of the cores, the distance between each core, their length and the thickness of the different units are drawn to scale. (a) Present day: evidence of river input from the West. The topography is obtained from our bathymetric data (b) at 1000/1154 cal. CE: evidence of a $\sim 40 \mathrm{~cm}$ vertical offset on the fault (c) before the last fault rupture. The table represents the deviation in sediment thicknesses (in $\mathrm{cm}$ ) for each core and stratigraphic unit relative to Core IZN19_21. The colors are the same as in Figure 6. 
footwall of the fault for the green unit as opposed to only a minor relative difference in thickness for the orange unit just below (Figure 9). This thickness variation reflects the fault activity. The co-seismic vertical offset created an accommodation space on the footwall of the fault which then has been gradually filled (Figure 9b). Part of this thickness variation on both side of the fault can also be due to the dextral co-seismic offset that bring finer sediments on the northern compartment of the fault compare to more proximal and thicker ones in the southern compartment. The observation of an event deposit at the base of this green unit also supports this interpretation of fault rupture (Figure 8a). The turbidity current-induced deposit is a co-seismic marker while the sedimentary thickness variation is a syn- to post-seismic indicator. This co-seismic event deposit is dated between 1000 and 1154 cal. CE and thus coincides with the well-documented 1065 CE earthquake (Ambraseys, 2009). The independent archeo-seismological study of Benjelloun et al. (2020), documents an important phase of reconstruction of Nicaea's buildings (formerly Iznik) between 858 and 1097 CE. According to the original historical archive (Michael \& Attaleiatēs, 2012), the 1065 CE earthquake has strongly damaged the city of Iznik (formerly Nicaea/Nikaia): "It happened at Nikaia in Bithynia and brought almost total devastation and ruin to the place. Its most important and large churches [...] and the one of the Holy Fathers, where the Council of the most Holy and Orthodox Fathers against Areios confirmed its decisions [...] those churches, then, were shaken and collapsed as did the walls of the city along with many private dwellings." No other locality seems to have been damaged as strongly as Iznik during this earthquake, which suggests a proximal event rupturing the MNAF. The $\sim 40 \mathrm{~cm}$ vertical co-seismic offset associated to the dextral one and the co-seismic turbidites could have triggered a destructive wave (tsunami). This $1065 \mathrm{CE}$ earthquake may have also induced ground-level variation that led to the destruction and submersion of the basilica of Nicaea (Şahin, 2014), explaining why this basilica has never been rebuilt.

As shown in Figure 8, the 1065 CE earthquake should not be recorded in our cores if we consider the epicenter location deduced from historical archives $>20 \mathrm{~km}$ east of Iznik (Ambraseys, 2002) and it has not been documented neither in other lake (e.g., Sapanca) nor in the Marmara Sea basins (e.g., Yakupoğlu et al., 2019). However, we show in this study that both an event deposit and a sedimentary unit with a vertical offset by $\sim 40 \mathrm{~cm}$ are dated to that period. As this earthquake clearly ruptured the Iznik Fault up to the lake floor we propose to relocate its epicenter in the lake (black arrow on Figure 8). As McHugh et al. (2014) reported, the location of historical earthquakes can present big errors since the fault segments within the Marmara Sea and the different lakes were not known before the 1999 CE Izmit Earthquake.

The most recent unit (pink in Figure 9a) postdates 1470/1777 cal. CE and shows a thickness increase of $\sim 44 \mathrm{~cm}$ in the southernmost shore-proximal Core IZN19_04. Bathymetric data suggest a recent delta-derived clastic contribution to explain this thickness variation. The recent increase of erosion and sediment supply to the lake is likely related to agriculture revival in the catchment (Martin, 2001).

The lowermost stratigraphic unit found in our cores, the unit marked in gray, is $62 \mathrm{~cm}$ thicker on the southern side of the fault $(62 \mathrm{~cm}$ vs. $<130 \mathrm{~cm}$ ) (Figure 9c). Such a variation could be also caused by movements of the fault during former earthquakes before the common era, suggesting thousand years of recurrence on this fault segment. But longer sequences are required on both side of the fault to retrieved the base of the gray unit and infer the pre-gray unit topography to confirm this hypothesis. Further seismic acquisitions could also help to highlight and image stratigraphically deeper units in the hanging wall (e.g., Beck et al., 2012), and to identify the horizontal offset along the fault. The core locations are ideal to identify the rupture on the Iznik Fault, but cores in the deepest sub-basins could be more prone to records an earthquake catalogue (e.g., McHugh et al., 2014).

\subsection{Regional Tectonics}

Looking at a larger scale, the identification of an earthquake rupture on the Iznik Fault in $1065 \mathrm{CE}$ is of major importance as it belongs to the MNAF system. According to the synthesis of Drab et al. (2015), a sequence of earthquakes is observed from 865 to 1063 along the NNAF, with a seismic gap within the central Marmara Sea, quite similar as the one we observed presently. The $1065 \mathrm{CE}$ earthquake that occurs on the MNAF accommodates part of the accumulated stress at the NAF scale, showing the complexity of this system of faults. The fact that this Iznik Fault has not ruptured since almost thousand years (last rupture in $1065 \mathrm{CE}$ ) and that a gap of seismicity is observed all along the MNAF, the seismic hazard increases a lot in this area. 


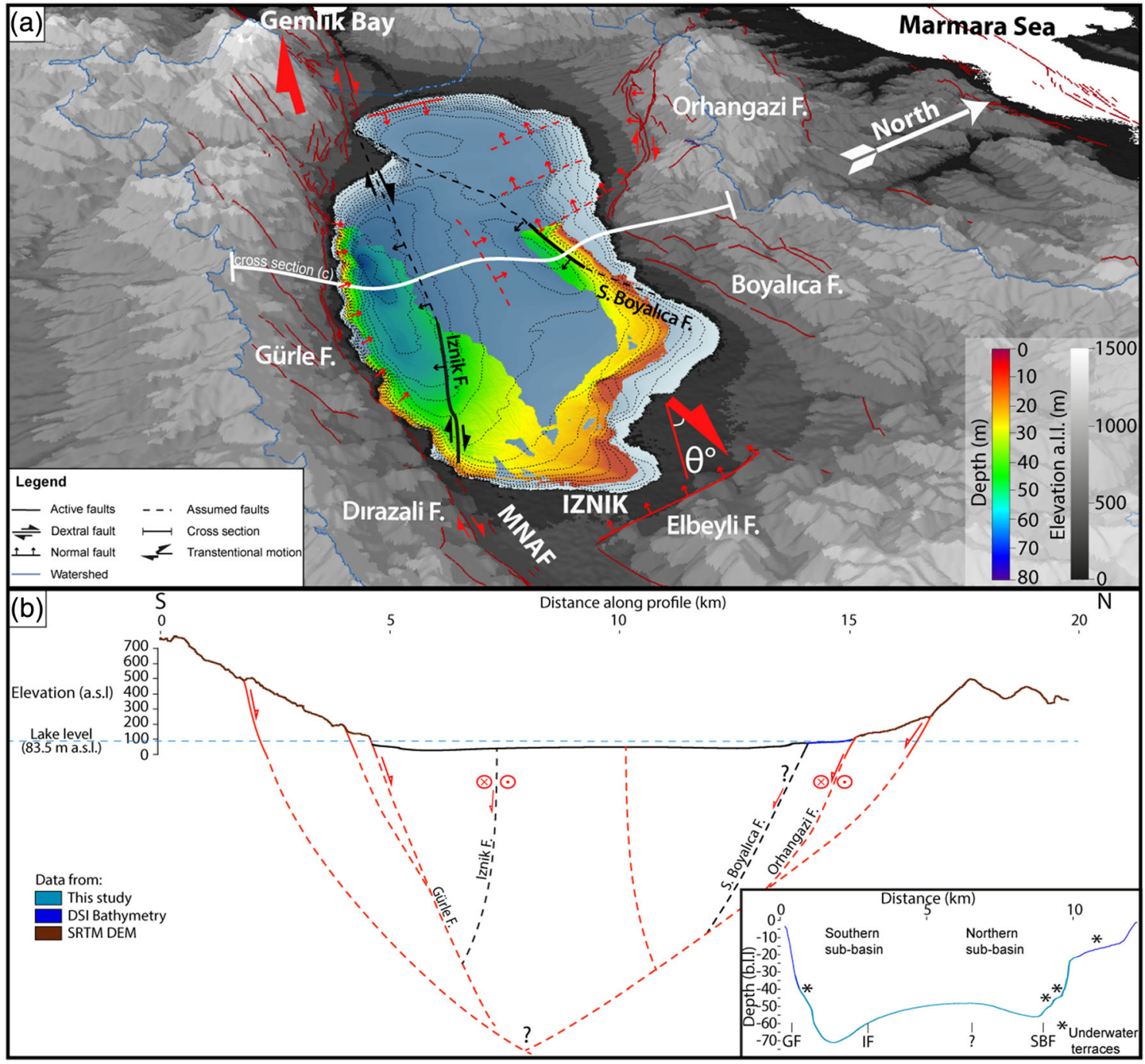

Figure 10. (a) 3D visualization derived from SRTM DEM (1 arc-second resolution) of the Iznik Basin with tectonic interpretation. The bathymetry carried out in this study is superimposed on the DSI bathymetry. The red solid lines are active faults from the literature (Benjelloun, 2017; Doğan et al., 2015; Emre et al., 2018; Ozturk et al., 2009), whereas the red dashed lines represent presumed faults. The black lines represent newly discovered fault structures documented in this study. The blue line represents the limit of the catchment of Lake Iznik. A vertical exaggeration of 3 is applied on each data set. (b) N-S profile across the lake (see (a) for location), with tectonic interpretation. The black fault lines represent the two faults documented in this study. Inset is a zoom of the lake bathymetry. GF: Gürle Fault; IF: Iznik Fault; SBF: South Boyalıca Fault; *: Underwater terraces.

Linear strike-slip faults such as the Iznik Fault are important tectonic structures as shown by the one discovered along the NNAF within the Izmit-Sapanca segment during the Izmit 1999 earthquake (Michel \& Avouac, 2002). The rupture along this straight segment was of supershear nature and caused strong damages amplified by ground liquefaction (Bouchon, 2002). The presented newly discovered faults provide essential data showing that the MNAF should be seriously consider in the assessment of seismic hazard of the region.

The description of the whole active fault system in and around Lake Iznik also improves tectonic knowledge. The Gürle and Orhangazi normal faults bounded the underwater Iznik and South Boyalıca faults, resulting in a negative flower structure linked to the MNAF system, as shown on the simplified NS cross section of the lake (Demirel et al., 2020; Figure 10b). Lake Iznik exhibits three sub-basins that cannot be explained in a simple pull-apart process approach (Dooley \& Schreurs, 2012; Wu et al., 2009). The South Boyalica Fault presented in this study seems to delimit the western sub-basin from the two others (Figures 10a), when the Iznik Fault delineates the southern basin. Models of transtensional pull-apart basins, due to an oblique and 
divergent displacement at a $\theta$ angle with the main strike-slip fault show similar sub-basins delineated by faults (Dooley \& Schreurs, 2012; Wu et al., 2009; Figure 10a). This hypothesis of transtension is supported by the GPS data along the MNAF in this area (Akay \& Ozener, 2009).

The discovery of the Iznik strike-slip Fault also suggests fault partitioning of the MNAF close to Lake Iznik. The onshore Gürle Fault accommodates mostly the normal component and controls the deepest basin of the lake whereas the Iznik Fault accommodates the right-lateral component of the MNAF system, controlling the shape of the southern sub-basin (Figure 10). Two smaller N-S extensional fault segments were observed on the western sub-basin (Öztürk et al., 2009) and to the East of the city of Iznik (the Ebeyli Fault) (Benjelloun et al., 2018). Scarps with similar srike are observed in the bathymetric map from the DSI that need to be studied more closely (Figure 10a). Further, bathymetric and seismic surveys will provide key elements to understand the timing of these tectonic controls. Airgun seismic data could also provide more information on the fault activities over time and image the subsurface continuation of the fault (e.g., de La Taille et al., 2015).

\section{Conclusions}

The sedimentary study done on the cores sampled in the Lake Iznik revealed 14 earthquake-induced turbidite deposits since their ages correspond to historical regional seismic events during the past two millennia, allowing to refine the calendar of historical seismicity in this region (29-32, 69, 121, 269, 358, and 362 CE or $368,407,447,478,554,869,989,1065$, and $1959 \mathrm{CE})$. At least three of them are related to the MNAF rupture $(32,121$, and $1065 \mathrm{CE})$.

The combined geophysical and sedimentological approach in Lake Iznik allows to discover two active subaquatic faults, the South Boyalıca and Iznik faults, that form part of the middle strand of the North Anatolian Fault system and that are responsible for some of the recorded earthquakes in the lake. The sedimentological study focused on both part of the Iznik Fault shows paleo-seismological evidences for a last rupture that occurred during the devastating $1065 \mathrm{CE}$ earthquake. Longer sequences from the same locations associated to on-fault studies are needed to determine the earthquake recurrence interval on the Iznik Fault which seems to be close to 1,000 years. The seismic gap since $1065 \mathrm{CE}$ of this Iznik Fault segment strongly increases the seismic hazard in the region of Iznik and must be taken into account for the seismic risk assessment of the NAF system. At the scale of the NAF system the $1065 \mathrm{CE}$ earthquake could belongs to the sequence of earthquakes from $865 \mathrm{CE}$ to $1065 \mathrm{CE}$, when a seismic gap was subsisting along the NNAF within the central Marmara, showing that the MNAF takes an active part in the seismic cycle of the NAF.

Finally, our findings provide a better understanding of the Lake Iznik tectonic context that presents a negative flower structure with a transtensional component.

\section{Data Availability Statement}

Supplementary data reported in this study are given in the supporting information, and all core and geophysical data are stored in Pangaea database (at https://doi.org/10.1594/PANGAEA.924472, https://doi.org/ 10.1594/PANGAEA.924476, https://doi.org/10.1594/PANGAEA.924477, https://doi.org/10.1594/PANGAE A.924479, https://doi.org/10.1594/PANGAEA.924482, https://doi.org/10.1594/PANGAEA.924483, https:// doi.org/10.1594/PANGAEA.924489, https://doi.org/10.1594/PANGAEA.924492, https://doi.org/10.1594/ PANGAEA.924495, https://doi.org/10.1594/PANGAEA.924496, and https://doi.org/10.1594/PANGAEA. 924497).

\section{References}

Akay, G., \& Ozener, H. (2009). Investigation of long period crustal deformation on the inactive branch of the North Anatolian Fault Zone. Natural Hazards and Earth System Sciences, 9(3), 663-671. https://doi.org/10.5194/nhess-9-663-2009

Alpar, B., \& Yaltirak, C. (2002). Characteristic features of the North Anatolian Fault in the eastern Marmara region and its tectonic evolution. Marine Geology, 190(1-2), 329-350. https://doi.org/10.1016/S0025-3227(02)00353-5

Ambraseys (2002). The seismic activity of the Marmara Sea region over the last 2000 years. Bulletin of the Seismological Society of America, 92(1), 1-18. https://doi.org/10.1785/0120000843

Ambraseys (2009). Earthquakes in the Mediterranean and Middle East: A multidisciplinary study of seismicity up to 1900. Cambridge: Cambridge University Press. https://doi.org/10.1017/CBO9781139195430

Ambraseys, N. N., \& Finkel, C. (1991). Long-term seismicity of Istanbul and of the Marmara Sea region. Terra Nova, 3(5), 527-539. https:// doi.org/10.1111/j.1365-3121.1991.tb00188.x 
Ambraseys, N. N., \& Jackson, J. A. (2000). Seismicity of the Sea of Marmara (Turkey) since 1500. Geophysical Journal International, 141(3), F1-F6. https://doi.org/10.1046/j.1365-246x.2000.00137.x

Armijo, R., Pondard, N., Meyer, B., Uçarkus, G., de Lépinay, B. M., Malavieille, J., et al. (2005). Submarine fault scarps in the Sea of Marmara pull-apart (North Anatolian Fault): Implications for seismic hazard in Istanbul. Geochemistry, Geophysics, Geosystems, 6, Q06009. https://doi.org/10.1029/2004GC000896

Arnaud, F., Poulenard, J., Giguet-Covex, C., Wilhelm, B., Révillon, S., Jenny, J.-P., et al. (2016). Erosion under climate and human pressures: An alpine lake sediment perspective. Quaternary Science Reviews, 152, 1-18. https://doi.org/10.1016/j.quascirev.2016.09.018

Avşar, U., Hubert-Ferrari, A., De Batist, M., Schmidt, S., \& Fagel, N. (2015). Sedimentary records of past earthquakes in Boraboy Lake during the last ca 600 years (North Anatolian Fault, Turkey). Palaeogeography, Palaeoclimatology, Palaeoecology, 433, 1-9. https://doi. org/10.1016/j.palaeo.2015.04.031

Bajard, M., Poulenard, J., Sabatier, P., Develle, A.-L., Giguet-Covex, C., Jacob, J., et al. (2017). Progressive and regressive soil evolution phases in the Anthropocene. Catena, 150, 39-52. https://doi.org/10.1016/j.catena.2016.11.001

Barka, A. (1993). Kuzey Anadolu Fayının Sapanca-İzmit ve Geyve-İznik kolları üzerinde paleosismik araştırmalar. TÜBİTAK Proje No: YBAG-4/7551, 85.

Beck, C., Campos, C., Eriş, K. K., Çağatay, N., Mercier de Lepinay, B., \& Jouanne, F. (2015). Estimation of successive coseismic vertical offsets using coeval sedimentary events-Application to the southwestern limit of the Sea of Marmara's Central Basin (North Anatolian Fault). Natural Hazards and Earth System Sciences, 15(2), 247-259. https://doi.org/10.5194/nhess-15-247-2015

Beck, C., Reyss, J.-L., Leclerc, F., Moreno, E., Feuillet, N., Barrier, L., et al. (2012). Identification of deep subaqueous co-seismic scarps through specific coeval sedimentation in Lesser Antilles: Implication for seismic hazard. Natural Hazards and Earth System Sciences, 12(5), 1755-1767. https://doi.org/10.5194/nhess-12-1755-2012

Beck, C. (2009). Late Quaternary lacustrine paleo-seismic archives in north-western Alps: Examples of earthquake-origin assessment of sedimentary disturbances. Earth-Science Reviews, 96(4), 327-344. https://doi.org/10.1016/j.earscirev.2009.07.005

Benjelloun, Y., de Sigoyer, J., Dessales, H., Baillet, L., Guéguen, P., \& Şahin, M. (2020). Historical earthquake scenarios for the middle strand of the North Anatolian Fault deduced from archeo-damage inventory and building deformation modeling. Seismological Research Letters. https://doi.org/10.1785/0220200278

Benjelloun, Y., de Sigoyer, J., Dessales, H., Garambois, S., \& Şahin, M. (2018). Construction history of the aqueduct of Nicaea (Iznik, NW Turkey) and its on-fault deformation viewed from archaeological and geophysical investigations. Journal of Archaeological Science: Reports, 21, 389-400. https://doi.org/10.1016/j.jasrep.2018.08.010

Blaauw, M. (2010). Methods and code for "classical” age-modelling of radiocarbon sequences. Quaternary Geochronology, 5(5), 512-518. https://doi.org/10.1016/j.quageo.2010.01.002

Bouchon, M. (2002). Space and time evolution of rupture and faulting during the 1999 Izmit (Turkey) earthquake. Bulletin of the Seismological Society of America, 92(1), 256-266. https://doi.org/10.1785/0120000845

Brocard, G., Anselmetti, F. S., \& Teyssier, C. (2016). Guatemala paleoseismicity: From Late Classic Maya collapse to recent fault creep. Scientific Reports, 6, 36976. https://doi.org/10.1038/srep36976

Bulut, F., Aktuğ, B., Yaltırak, C., Doğru, A., \& Özener, H. (2019). Magnitudes of future large earthquakes near Istanbul quantified from 1500 years of historical earthquakes, present-day microseismicity and GPS slip rates. Tectonophysics, 764, 77-87. https://doi.org/10.1016/ j.tecto.2019.05.005

Çağatay, M., Erel, L., Bellucci, L., Polonia, A., Gasperini, L., Eriş, K., et al. (2012). Sedimentary earthquake records in the İzmit Gulf, Sea of Marmara, Turkey. Sedimentary Geology, 282, 347-359. https://doi.org/10.1016/j.sedgeo.2012.10.001

Cetin, K. O., Youd, T. L., Seed, R. B., Bray, J. D., Sancio, R., Lettis, W., et al. (2002). Liquefaction-induced ground deformations at Hotel Sapanca during Kocaeli (Izmit), Turkey earthquake. Soil Dynamics and Earthquake Engineering, 22(9-12), 1083-1092. https://doi.org/ 10.1016/S0267-7261(02)00134-3

Cukur, D., Krastel, S., Demirel-Schlüter, F., Demirbağ, E., Imren, C., Niessen, F., \& Toker, M. (2013). Sedimentary evolution of Lake Van (Eastern Turkey) reconstructed from high-resolution seismic investigations. International Journal of Earth Sciences, 102(2), 571-585. https://doi.org/10.1007/s00531-012-0816-X

de La Taille, C., Jouanne, F., Crouzet, C., Beck, C., Jomard, H., de Rycker, K., \& van Daele, M. (2015). Impact of active faulting on the post LGM infill of Le Bourget Lake (western Alps, France). Tectonophysics, 664, 31-49. https://doi.org/10.1016/j.tecto.2015.08.024

Demirel, S., Alpar, B., Yaltırak, C., Vardar, D., \& Kurt, H. (2020). Northern segment of the North Anatolian Fault in the Gulf of Izmit inferred from marine magnetic anomalies. Marine Geophysical Research, 41, 6. https://doi.org/10.1007/s11001-020-09399-6

Doğan, B. (2010). Kuzey Anadolu Fay Sistemi Güney Kolunun Geyve-gemlik Arasındaki Kesiminin Morfotektonik, Tektonostratigrafik Ve Paleosismolojik Evrimi (PhD Thesis). Fen Bilimleri Enstitüsü.

Doğan, B., Tüysüz, O., \& Şanlı, F. B. (2015). Tectonostratigraphic evolution of the basins on the southern branch of the North Anatolian Fault System in the SE Marmara Region, Turkey. International Journal of Earth Sciences, 104(2), 389-418. https://doi.org/10.1007/ s00531-014-1083-9

Dooley, T. P., \& Schreurs, G. (2012). Analogue modelling of intraplate strike-slip tectonics: A review and new experimental results. Tectonophysics, 574, 1-71.

Drab, L., Hubert, A., Schmidt, S., \& Martinez, P. (2012). The earthquake sedimentary record in the western part of the Sea of Marmara, Turkey. Natural Hazards and Earth System Sciences, 12(4), 1235-1254. https://doi.org/10.5194/nhess-12-1235-2012

Drab, L., Hubert-Ferrari, A., Schmidt, S., Martinez, P., Carlut, J., \& Ouahabi, M. E. (2015). Submarine earthquake history of the Çınarcık segment of the North Anatolian Fault in the Marmara Sea, TurkeySubmarine earthquake history of the Çınarcik segment of the NAF in the Marmara Sea, Turkey. Bulletin of the Seismological Society of America, 105(2A), 622-645. https://doi.org/10.1785/0120130083

Emre, Ö., Duman, T. Y., Özalp, S., Şaroğlu, F., Olgun, Ş., Elmacı, H., \& Çan, T. (2018). Active fault database of Turkey. Bulletin of Earthquake Engineering, 16(8), 3229-3275. https://doi.org/10.1007/s10518-016-0041-2

Ergintav, S., Reilinger, R., Çakmak, R., Floyd, M., Cakir, Z., Doğan, U., et al. (2014). Istanbul's earthquake hot spots: Geodetic constraints on strain accumulation along faults in the Marmara seismic gap. Geophysical Research Letters, 41, 5783-5788. https://doi.org/10.1002/ 2014GL060985

Eriş, K. K., Çağatay, N., Beck, C., de Lepinay, B. M., \& Corina, C. (2012). Late-Pleistocene to Holocene sedimentary fills of the Çınarcık Basin of the Sea of Marmara. Sedimentary Geology, 281, 151-165. https://doi.org/10.1016/j.sedgeo.2012.09.001

Eriş, K. K., Sabuncu, A., Gasperini, L., Polonia, A., \& Kındap, T. (2019). Influence of climate on the late Pleistocene depositional history of the Gulf of Gemlik (Sea of Marmara). Geo-Marine Letters, 39(3), 205-221. https://doi.org/10.1007/s00367-019-00568-0

Evans, J. A. S. (2005). The Emperor Justinian and the Byzantine Empire. Westport, Connecticut (US): Greenwood Publishing Group. 
Girardclos, S., Schmidt, O. T., Sturm, M., Ariztegui, D., Pugin, A., \& Anselmetti, F. S. (2007). The 1996 AD delta collapse and large turbidite in Lake Brienz. Marine Geology, 241(1-4), 137-154. https://doi.org/10.1016/j.margeo.2007.03.011

Guevara, S. R., Rizzo, A., Daga, R., Williams, N., \& Villa, S. (2019). Bromine as indicator of source of lacustrine sedimentary organic matter in paleolimnological studies. Quaternary Research, 92(1), 257-271. https://doi.org/10.1017/qua.2018.125

Guidoboni, E., \& Comastri, A. (2005). Catalogue of Earthquakes and Tsunamis in the Mediterranean Area from the 11th to the 15th Century. Rome, Italy: Istituto nazionale di geofisica e vulcanologia.

Guidoboni, E., Comastri, A., Traina, G., \& di Geofisica, R. I. N. (1994). Catalogue of ancient earthquakes in the Mediterranean area up to the 10th century. Istituto nazionale di geofisica Rome.

Gurbuz, C., Aktar, M., Eyidogan, H., Cisternas, A., Haessler, H., Barka, A., et al. (2000). The seismotectonics of the Marmara region (Turkey): Results from a microseismic experiment. Tectonophysics, 316(1-2), 1-17. https://doi.org/10.1016/S0040-1951(99)00253-X

Hage, S., Hubert-Ferrari, A., Lamair, L., Avşar, U., el Ouahabi, M., van Daele, M., et al. (2017). Flow dynamics at the origin of thin clayey sand lacustrine turbidites: Examples from Lake Hazar, Turkey. Sedimentology, 64(7), 1929-1956. https://doi.org/10.1111/sed.12380

Heiri, O., Lotter, A. F., \& Lemcke, G. (2001). Loss on ignition as a method for estimating organic and carbonate content in sediments: Reproducibility and comparability of results. Journal of Paleolimnology, 25(1), 101-110. https://doi.org/10.1023/A:1008119611481

Hilbe, M., \& Anselmetti, F. S. (2014). Signatures of slope failures and river-delta collapses in a perialpine lake (Lake Lucerne, Switzerland). Sedimentology, 61(7), 1883-1907. https://doi.org/10.1111/sed.12120

Honkura, Y., \& Işikara, A. M. (1991). Multidisciplinary research on fault activity in the western part of the North Anatolian Fault Zone. Tectonophysics, 193(4), 347-357. https://doi.org/10.1016/0040-1951(91)90343-Q

Hubert-Ferrari, A., Barka, A., Jacques, E., Nalbant, S. S., Meyer, B., Armijo, R., et al. (2000). Seismic hazard in the Marmara Sea region following the 17 August 1999 Izmit earthquake. Nature, 404(6775), 269-273. https://doi.org/10.1038/35005054

Hubert-Ferrari, A., Lamair, L., Hage, S., Schmidt, S., Çağatay, M. N., \& Avşar, U. (2020). A 3800 yr paleoseismic record (Lake Hazar sediments, eastern Turkey): Implications for the East Anatolian Fault seismic cycle. Earth and Planetary Science Letters, $538,116152$. https://doi.org/10.1016/j.epsl.2020.116152

Kurt, H., Sorlien, C., Seeber, L., Steckler, M., Shillington, D., Cifci, G., et al. (2013). Steady late quaternary slip rate on the Cinarcik section of the North Anatolian fault near Istanbul, Turkey. Geophysical Research Letters, 40, 4555-4559. https://doi.org/10.1002/grl.50882

Kurtuluş, C., \& Canbay, M. M. (2007). Tracing the middle strand of the North Anatolian Fault Zone through the southern Sea of Marmara based on seismic reflection studies. Geo-Marine Letters, 27(1), 27-40. https://doi.org/10.1007/s00367-006-0050-2

Lange, D., Kopp, H., Royer, J.-Y., Henry, P., Çakir, Z., Petersen, F., et al. (2019). Interseismic strain build-up on the submarine North Anatolian Fault offshore Istanbul. Nature Communications, 10, 3006. https://doi.org/10.1038/s41467-019-11016-Z

Martin, J. M. (Ed.) (2001). Castrum 7: Zones côtières littorales dans le monde Méditerranéen au Moyen Âge: Défense, peuplement, mise en valeur (Vol. 76). Casa de Velázquez.

McHugh, C. M., Seeber, L., Cormier, M.-H., Dutton, J., Cagatay, N., Polonia, A., et al. (2006). Submarine earthquake geology along the North Anatolia Fault in the Marmara Sea, Turkey: A model for transform basin sedimentation. Earth and Planetary Science Letters, 248(3-4), 661-684. https://doi.org/10.1016/j.epsl.2006.05.038

McHugh, C. M. G., Braudy, N., Çağatay, M. N., Sorlien, C., Cormier, M.-H., Seeber, L., \& Henry, P. (2014). Seafloor fault ruptures along the North Anatolia Fault in the Marmara Sea, Turkey: Link with the adjacent basin turbidite record. Marine Geology, 353, 65-83. https://doi. org/10.1016/j.margeo.2014.03.005

Michael, A., \& Attaleiatēs, M. (2012). The history (Vol. 16). Cambridge, MA, US: Harvard University Press.

Michel, R., \& Avouac, J.-P. (2002). Deformation due to the 17 August 1999 Izmit, Turkey, earthquake measured from SPOT images. Journal of Geophysical Research, 107(B4), 2062. https://doi.org/10.1029/2000JB000102

Miebach, A., Niestrath, P., Roeser, P., \& Litt, T. (2016). Impacts of climate and humans on the vegetation in northwestern Turkey: Palynological insights from Lake Iznik since the Last Glacial. Climate of the Past, 12(2), 575-593. https://doi.org/10.5194/cp-12-575-2016

Moernaut, J., Van Daele, M., Strasser, M., Clare, M. A., Heirman, K., Viel, M., et al. (2017). Lacustrine turbidites produced by surficial slope sediment remobilization: A mechanism for continuous and sensitive turbidite paleoseismic records. Marine Geology, 384, $159-176$. https://doi.org/10.1016/j.margeo.2015.10.009

Monecke, K., Anselmetti, F. S., Becker, A., Sturm, M., \& Giardini, D. (2004). The record of historic earthquakes in lake sediments of Central Switzerland. Tectonophysics, 394(1-2), 21-40. https://doi.org/10.1016/j.tecto.2004.07.053

Munsell Color (1994). Munsell soil color charts. Macbeth, Division of Kollmorgen Instruments Corporation. Newburgh, NY: Munsell Color.

Öcal, A. (2019). Natural disasters in Turkey: Social and economic perspective. International Journal of Disaster Risk Management, 1(1), 51-61. https://doi.org/10.18485/ijdrm.2019.1.1.3

Özalp, S., Emre, Ö., \& Dogan, A. (2013). The segment structure of southern branch of the North Anatolian Fault and paleoseismological behaviour of the Gemlik Fault, NW Anatolia. General Directorate of Mineral Research and Exploration (MTA) Bulletin, $147,1-17$.

Öztürk, K., Yaltirak, C., \& Alpar, B. (2009). The relationship between the tectonic setting of the Lake Iznik basin and the middle strand of the North Anatolian Fault. Turkish Journal of Earth Sciences, 18(2), 209-224.

Parsons, T. (2000). Heightened odds of large earthquakes near Istanbul: An interaction-based probability calculation. Science, 288(5466), 661-665. https://doi.org/10.1126/science.288.5466.661

R Core Team (2018). R: A language and environment for statistical computing. Vienna, Austria: R Foundation for Statistical Computing. Retrieved from. https://www.R-project.org/

Rapuc, W., Sabatier, P., Andrič, M., Crouzet, C., Arnaud, F., Chapron, E., et al. (2018). 6600 years of earthquake record in the Julian Alps (Lake Bohinj, Slovenia). Sedimentology, 65(5), 1777-1799. https://doi.org/10.1111/sed.12446

Reilinger, R., McClusky, S., Vernant, P., Lawrence, S., Ergintav, S., Cakmak, R., et al. (2006). GPS constraints on continental deformation in the Africa-Arabia-Eurasia continental collision zone and implications for the dynamics of plate interactions. Journal of Geophysical Research, 111, B05411. https://doi.org/10.1029/2005JB004051

Reimer, P. J., Austin, W. E., Bard, E., Bayliss, A., Blackwell, P. G., Ramsey, C. B., et al. (2020). The IntCal20 Northern Hemisphere radiocarbon age calibration curve (0-55 cal kBP). Radiocarbon, 62(4), 725-757. https://doi.org/10.1017/RDC.2020.41

Richter, T. O., van der Gaast, S., Koster, B., Vaars, A., Gieles, R., de Stigter, H. C., et al. (2006). The Avaatech XRF Core scanner: Technical description and applications to NE Atlantic sediments. Geological Society, London, Special Publications, 267(1), 39-50. https://doi.org/ 10.1144/GSL.SP.2006.267.01.03

Roeser, P., Franz, S. O., \& Litt, T. (2016). Aragonite and calcite preservation in sediments from Lake Iznik related to bottom lake oxygenation and water column depth. Sedimentology, 63(7), 2253-2277. https://doi.org/10.1111/sed.12306

Roeser, P. A. (2014). Paleolimnology of Lake Iznik (NW Turkey) during the past 31 ka cal BP. Retrieved from https://bonndoc.ulb. uni-bonn.de/xmlui/handle/20.500.11811/6103 
Roeser, P. A., Franz, S. O., Litt, T., Ülgen, U. B., Hilgers, A., Wulf, S., et al. (2012). Lithostratigraphic and geochronological framework for the paleoenvironmental reconstruction of the last $\sim 36 \mathrm{ka}$ cal BP from a sediment record from Lake Iznik (NW Turkey). Quaternary International, 274, 73-87. https://doi.org/10.1016/j.quaint.2012.06.006

Roodenberg, J. (2013). Change in food production and its impact on an early 6th millennium community in northwest Anatolia. The example of Ilıpınar. Praehistorische Zeitschrift, 87(2), 223-235.

Sabatier, P., Dezileau, L., Briqueu, L., Colin, C., \& Siani, G. (2010). Clay minerals and geochemistry record from northwest Mediterranean coastal lagoon sequence: Implications for paleostorm reconstruction. Sedimentary Geology, 228(3-4), 205-217. https://doi.org/10.1016/j. sedgeo.2010.04.012

Şahin, M. (2014). İznik Gölü'ndeki Batık Kilise: Deprem Kurbanı Aziz Neophytos. Aktüel Arkeoloji 38, Nisan, 8-10.

Sahin, M., \& Fairchild, M. R. (2018). Nicea's underwater basilica. Biblical Archaeology Review, 44(6), 30-37.

Schnellmann, M., Anselmetti, F. S., Giardini, D., \& McKenzie, J. A. (2005). Mass movement-induced fold-and-thrust belt structures in unconsolidated sediments in Lake Lucerne (Switzerland). Sedimentology, 52(2), 271-289. https://doi.org/10.1111/j.13653091.2004.00694.x

Sengör, A., Grall, C., İmren, C., Le Pichon, X., Görür, N., Henry, P., et al. (2014). The geometry of the North Anatolian transform fault in the Sea of Marmara and its temporal evolution: Implications for the development of intracontinental transform faults. Canadian Journal of Earth Sciences, 51(3), 222-242. https://doi.org/10.1139/cjes-2013-0160

Stein, R. S., Barka, A. A., \& Dieterich, J. H. (1997). Progressive failure on the North Anatolian fault since 1939 by earthquake stress triggering. Geophysical Journal International, 128(3), 594-604. https://doi.org/10.1111/j.1365-246X.1997.tb05321.x

Strasser, M., Anselmetti, F. S., Fäh, D., Giardini, D., \& Schnellmann, M. (2006). Magnitudes and source areas of large prehistoric northern Alpine earthquakes revealed by slope failures in lakes. Geology, 34(12), 1005-1008. https://doi.org/10.1130/G22784A.1

Strasser, M., Monecke, K., Schnellmann, M., \& Anselmetti, F. S. (2013). Lake sediments as natural seismographs: A compiled record of Late Quaternary earthquakes in Central Switzerland and its implication for Alpine deformation. Sedimentology, 60(1), 319-341. https://doi. org/10.1111/sed.12003

Tibi, R., Bock, G., Xia, Y., Baumbach, M., Grosser, H., Milkereit, C., et al. (2001). Rupture processes of the 1999 August 17 Izmit and November 12 Düzce (Turkey) earthquakes. Geophysical Journal International, 144(2), F1-F7. https://doi.org/10.1046/j.1365246x.2001.00360 x

Uçarkuş, G. (2002). Gemlik Fay Zonu'nun Aktif Tektoniği (Doctoral dissertation). İstanbul Teknik Üniversitesi.

Ülgen, U. B., Franz, S. O., Biltekin, D., Çagatay, M. N., Roeser, P. A., Doner, L., \& Thein, J. (2012). Climatic and environmental evolution of Lake Iznik (NW Turkey) over the last 4700 years. Quaternary International, 274, 88-101. https://doi.org/10.1016/j.quaint.2012.06.016

Van Daele, M., Moernaut, J., Doom, L., Boes, E., Fontijn, K., Heirman, K., et al. (2015). A comparison of the sedimentary records of the 1960 and 2010 great Chilean earthquakes in 17 lakes: Implications for quantitative lacustrine palaeoseismology. Sedimentology, 62(5), 1466-1496. https://doi.org/10.1111/sed.12193

Viehberg, F. A., Ülgen, U. B., Damc1, E., Franz, S. O., Ön, S. A., Roeser, P. A., et al. (2012). Seasonal hydrochemical changes and spatial sedimentological variations in Lake Iznik (NW Turkey). Quaternary International, 274, 102-111. https://doi.org/10.1016/j. quaint.2012.05.038

Wilhelm, B., Nomade, J., Crouzet, C., Litty, C., Sabatier, P., Belle, S., et al. (2016). Quantified sensitivity of small lake sediments to record historic earthquakes: Implications for paleoseismology: LAKE SENSITIVITY TO RECORD EARTHQUAKES. Journal of Geophysical Research: Earth Surface, 121, 2-16. https://doi.org/10.1002/2015JF003644

Wilhelm, B., Sabatier, P., \& Arnaud, F. (2015). Is a regional flood signal reproducible from lake sediments? Sedimentology, 62(4), 1103-1117. https://doi.org/10.1111/sed.12180

Wu, J. E., McClay, K., Whitehouse, P., \& Dooley, T. (2009). 4D analogue modelling of transtensional pull-apart basins. Marine and Petroleum Geology, 26(8), 1608-1623. https://doi.org/10.1016/j.marpetgeo.2008.06.007

Yakupoğlu, N., Uçarkuş, G., Eriş, K. K., Henry, P., \& Çağatay, M. N. (2019). Sedimentological and geochemical evidence for seismoturbidite generation in the Kumburgaz Basin, Sea of Marmara: Implications for earthquake recurrence along the Central High Segment of the North Anatolian Fault. Sedimentary Geology, 380, 31-44. https://doi.org/10.1016/j.sedgeo.2018.11.002

Yaltırak, C. (2002). Tectonic evolution of the Marmara Sea and its surroundings. Marine Geology, 190(1-2), 493-529. https://doi.org/ 10.1016/S0025-3227(02)00360-2 